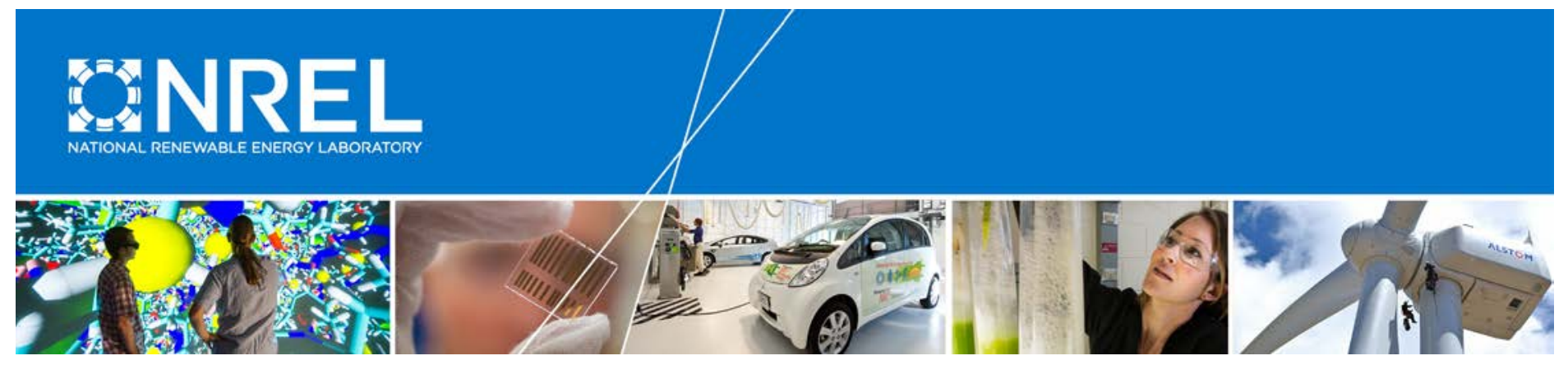

\title{
American Fuel Cell Bus Project Evaluation: Second Report
}

Leslie Eudy and Matthew Post National Renewable Energy Laboratory

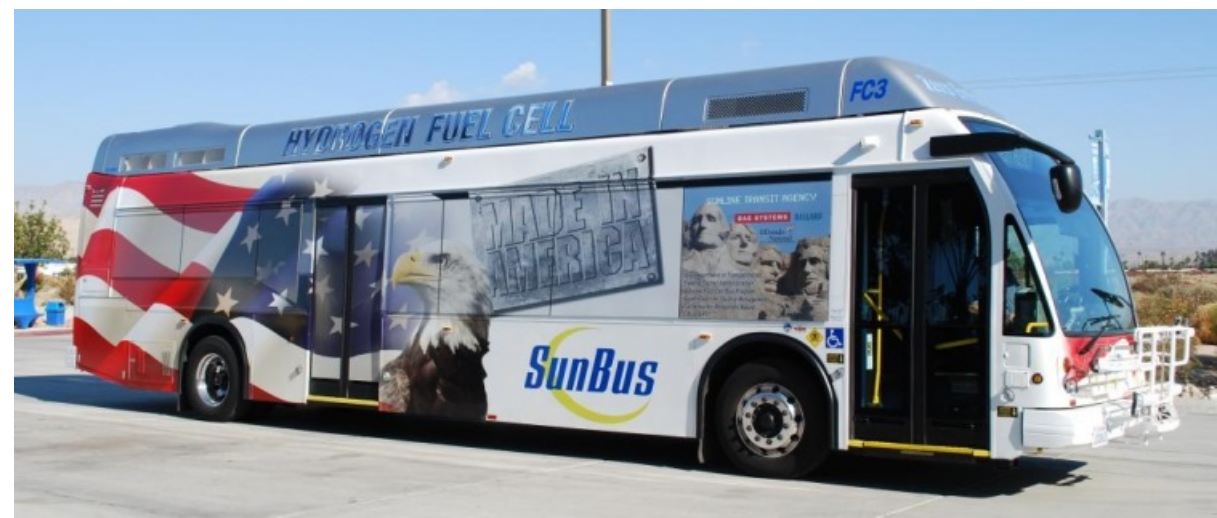

NREL is a national laboratory of the U.S. Department of Energy Office of Energy Efficiency \& Renewable Energy Operated by the Alliance for Sustainable Energy, LLC

This report is available at no cost from the National Renewable Energy Laboratory (NREL) at www.nrel.gov/publications.

Technical Report

NREL/TP-5400-64344

September 2015

Contract No. DE-AC36-08GO28308 


\section{American Fuel Cell Bus Project Evaluation: Second Report}

Leslie Eudy and Matthew Post

National Renewable Energy Laboratory

Prepared under Task No. HT12.8210
NREL is a national laboratory of the U.S. Department of Energy Office of Energy Efficiency \& Renewable Energy Operated by the Alliance for Sustainable Energy, LLC

This report is available at no cost from the National Renewable Energy Laboratory (NREL) at www.nrel.gov/publications.

\section{Technical Report}

NREL/TP-5400-64344

September 2015

Contract No. DE-AC36-08GO28308
15013 Denver West Parkway

Golden, CO 80401

303-275-3000 • www.nrel.gov 


\section{NOTICE}

This report was prepared as an account of work sponsored by an agency of the United States government. Neither the United States government nor any agency thereof, nor any of their employees, makes any warranty, express or implied, or assumes any legal liability or responsibility for the accuracy, completeness, or usefulness of any information, apparatus, product, or process disclosed, or represents that its use would not infringe privately owned rights. Reference herein to any specific commercial product, process, or service by trade name, trademark, manufacturer, or otherwise does not necessarily constitute or imply its endorsement, recommendation, or favoring by the United States government or any agency thereof. The views and opinions of authors expressed herein do not necessarily state or reflect those of the United States government or any agency thereof.

This report is available at no cost from the National Renewable Energy Laboratory (NREL) at www.nrel.gov/publications.

Available electronically at SciTech Connect http:/www.osti.gov/scitech

Available for a processing fee to U.S. Department of Energy and its contractors, in paper, from:

U.S. Department of Energy

Office of Scientific and Technical Information

P.O. Box 62

Oak Ridge, TN 37831-0062

OSTI http://www.osti.gov

Phone: 865.576.8401

Fax: 865.576.5728

Email: reports@osti.gov

Available for sale to the public, in paper, from:

U.S. Department of Commerce

National Technical Information Service

5301 Shawnee Road

Alexandria, VA 22312

NTIS http://www.ntis.gov

Phone: 800.553 .6847 or 703.605 .6000

Fax: 703.605.6900

Email: orders@ntis.gov 


\section{Acknowledgments}

This evaluation at SunLine would not have been possible without the support and cooperation of many people. The authors thank the following individuals:

U.S. Department of Energy (DOE)

Jason Marcinkoski

U.S. Department of Transportation Federal Transit Administration

Christina Gikakis

Sean Ricketson

DOE's National Renewable Energy Laboratory

Keith Wipke

Jen Kurtz

\section{SunLine Transit Agency}

Tommy Edwards

Polo Del Toro

Mike Hayes

Bill Loper

BAE Systems

Robert Devine

Yeshwanth Premkumar

Greg Marx

Ballard Power Systems

Jeff Grant

Byron Somerville

Steve Potvin

EIDorado National - California

Khalil Subat

CALSTART

Lawrence Wnuk

Unless otherwise noted, all photos and illustrations by L. Eudy, NREL 


\section{Acronyms and Abbreviations}

$\begin{array}{ll}\text { AFCB } & \text { American Fuel Cell Bus } \\ \text { Ah } & \text { amp-hours } \\ \text { DGE } & \text { diesel gallon equivalent } \\ \text { DOE } & \text { U.S. Department of Energy } \\ \text { FCEB } & \text { fuel cell electric bus } \\ \text { FCEV } & \text { fuel cell electric vehicle } \\ \text { FCPP } & \text { fuel cell power plant } \\ \text { ft } & \text { feet } \\ \text { FTA } & \text { Federal Transit Administration } \\ \text { GGE } & \text { gasoline gallon equivalent } \\ \text { GVWR } & \text { gross vehicle weight rating } \\ \text { hp } & \text { horsepower } \\ \text { HVAC } & \text { heating, ventilation, and air conditioning } \\ \text { in. } & \text { inches } \\ \text { kg } & \text { kilograms } \\ \text { kW } & \text { kilowatts } \\ \text { kWh } & \text { kilowatt hours } \\ \text { lb } & \text { pounds } \\ \text { MBRC } & \text { miles between roadcalls } \\ \text { mpDGE } & \text { miles per diesel gallon equivalent } \\ \text { mpg } & \text { miles per gallon } \\ \text { mph } & \text { miles per hour } \\ \text { NREL } & \text { National Renewable Energy Laboratory } \\ \text { OEM } & \text { original equipment manufacturer } \\ \text { PMI } & \text { preventive maintenance inspection } \\ \text { PRD } & \text { pressure relief device } \\ \text { psi } & \text { pounds per square inch } \\ \text { RC } & \text { roadcall } \\ \text { SI } & \text { International System of Units } \\ \text { ZBus } & \text { zero emission bus } \\ & \end{array}$




\section{Executive Summary}

This report presents results of the American Fuel Cell Bus (AFCB) Project, a demonstration of fuel cell electric buses (FCEB) operating in the Coachella Valley area of California. The prototype AFCB was developed as part of the Federal Transit Administration's (FTA) National Fuel Cell Bus Program. Through the non-profit consortia CALSTART, a team led by SunLine Transit Agency and BAE Systems developed a new FCEB for demonstration. SunLine added two more AFCBs to its fleet in 2014 and another in 2015. The report summarizes the performance results for the buses through June 2015.

The AFCB, built on an ElDorado National 40-foot Axess bus platform, has a fuel-cell-dominant hybrid electric propulsion system in a series configuration. BAE Systems based the prototype AFCB propulsion system on its commercial hybrid electric transit bus product, modified to provide power with a $150-\mathrm{kW}$ Ballard fuel cell system in place of a diesel engine/generator. The AFCB was delivered to SunLine in November 2011 and was put in revenue service in midDecember 2011. The manufacturer team used the early demonstration experience of the prototype bus to make modifications and updates to the system for the next three buses. While the basic design components are the same as that of the prototype, the newer buses feature refinements that should make servicing easier and increase reliability. Changes included a separate cooling system for batteries, a simplified power conversion system, software upgrades, and an improved radiator design to increase integrity. Two new AFCBs were delivered in June/July of 2014 and a third new AFCB was delivered in February 2015.

FTA and the AFCB project team are collaborating with the U.S. Department of Energy (DOE) and DOE's National Renewable Energy Laboratory (NREL) to evaluate the buses in revenue service. NREL has been evaluating FCEBs under funding from FTA and DOE and uses a standard data-collection and analysis protocol originally developed for DOE heavy-duty vehicle evaluations.

The focus of this evaluation is to compare performance of the FCEBs to that of conventional technology and to track progress over time toward meeting the technical targets set by DOE and FTA. In the commercialization process that begins at technology readiness level (TRL) 1 - basic research/concept - and ends at TRL 9-commercial deployment, NREL considers the AFCBs to be at TRL 7. At this point of development, the manufacturers' goals for the demonstration are to verify that the FCEB performance meets the DOE/FTA technical targets and identify any issues that need to be resolved. NREL collects data on five compressed natural gas (CNG) buses as a baseline comparison at SunLine.

This report focuses on the AFCB's performance from March 2013 through June 2015. For this 28-month period, the AFCB prototype bus operated during the entire time, while the three additional AFCBs operated for 12 months, 7 months, and 2 months. Table ES- 1 provides a summary of results for several categories of data presented in this report. Data are included on the AFCBs and on the five CNG baseline buses. The data analysis is shown for the entire demonstration as well as for the report evaluation period. From the start of the demonstration through June 2015, the buses have traveled more than 151,000 miles and accumulated more than 10,000 hours on the fuel cell systems. 
Table ES-1. Summary of Evaluation Results

\begin{tabular}{|l|c|c|c|c|}
\hline \multicolumn{1}{|c|}{ Data Item } & $\begin{array}{c}\text { AFCB } \\
\text { All Data }\end{array}$ & $\begin{array}{c}\text { AFCB } \\
\text { Evaluation } \\
\text { Period Data }\end{array}$ & $\begin{array}{c}\text { CNG } \\
\text { All Data }\end{array}$ & $\begin{array}{c}\text { CNG } \\
\text { Evaluation } \\
\text { Period Data }\end{array}$ \\
\hline Number of buses & 4 & 4 & 5 & 5 \\
\hline Data period & $3 / 12-6 / 15$ & $3 / 13-6 / 15$ & $3 / 12-6 / 15$ & $3 / 13-6 / 15$ \\
\hline Number of months & 40 & 28 & 40 & 28 \\
\hline Total mileage in period & 151,935 & 108,947 & 898,670 & 670,440 \\
\hline Average monthly mileage per bus & 2,491 & 2,223 & 4,493 & 4,789 \\
\hline Total fuel cell operating hours & 10,297 & 7,539 & - & - \\
\hline Availability (85\% is target) & 70 & 66 & 85 & 88 \\
\hline Fuel economy (miles/kg or GGE) & 6.11 & 5.94 & 2.86 & 2.89 \\
\hline Fuel economy (miles per DGE ${ }^{a}$ ) & 6.90 & 6.72 & 3.20 & 3.22 \\
\hline Miles between roadcalls (MBRC) - all & 3,896 & 3,891 & 8,559 & 8,707 \\
\hline MBRC - propulsion only & 6,606 & 6,409 & 25,676 & 23,944 \\
\hline MBRC - fuel cell system only & 18,992 & 21,789 & - & - \\
\hline Total maintenance, ${ }^{b}$ /mile & 0.50 & 0.54 & 0.54 & 0.54 \\
\hline Maintenance - propulsion only, \$/mile & 0.28 & 0.34 & 0.24 & 0.24 \\
\hline
\end{tabular}

${ }^{\mathrm{a}}$ Diesel gallon equivalent.

${ }^{\mathrm{b}}$ Work order maintenance cost.

Overall, the AFCBs had an average fuel economy of 5.94 miles per kilogram of hydrogen, which equates to 6.72 miles per diesel gallon equivalent (DGE). Using the gasoline gallon equivalent (GGE) fuel economy of the CNG buses as a baseline, the AFCB fuel economy was 2 times higher than that of the $\mathrm{CNG}$ buses.

During the evaluation period, the average availability for the AFCBs was $66 \%$ compared to $88 \%$ for the $\mathrm{CNG}$ baseline buses. The issues causing downtime were most often related to general bus system items (54\% of total downtime) rather than the advanced technologies that were the focus of the demonstration. The primary issue affecting availability involved a coolant leak for the prototype bus. The leak proved difficult to diagnose, but it was eventually traced to a cracked radiator. The bus was out of service for 3 months. Prior to the issue, the bus had an average availability of $85 \%$.

Reliability, measured as miles between roadcalls (MBRC), continues to show improvement. The overall bus MBRC for the AFCBs is showing a slow increase over time and is nearing the target of 4,000 miles. The fuel cell MBRC shows a general upward trend and has passed the DOE/FTA 2016 target of 15,000 miles.

In addition to analyzing the FCEB performance, NREL provides a cost analysis and comparison. The current costs for FCEB technology - both capital and operating costs - are still much higher than the costs of conventional technology. This is expected when comparing a very mature technology, like CNG, to new technologies in the development stage. The AFCBs are still in the warranty period. The parts costs continue to be low for the AFCBs because parts for the propulsion system are typically covered by the manufacturer under warranty; however, SunLine's mechanics do nearly all of the work. SunLine's CNG buses were manufactured in 2008 and are out of the warranty period. Each of these buses has accumulated more than 350,000 miles and has reached the mid-life point where costs tend to increase. This is evident by the increased costs for engine and other propulsion system maintenance. 
Total maintenance costs per mile for the AFCBs during the data period were the same as that of the $\mathrm{CNG}$ buses. Propulsion-related system costs per mile accounted for $63 \%$ of the total costs for the AFCBs.

DOE and FTA have published performance, cost, and durability targets for FCEBs. These targets, established with industry input, include interim targets for 2016 and ultimate targets for commercialization. Table ES-2 summarizes the current performance of the AFCBs compared to these targets.

Table ES-2. Summary of AFCB Performance Compared to DOE/FTA Targets ${ }^{1}$

\begin{tabular}{|c|c|c|c|c|}
\hline & Units & This Report $^{\mathrm{a}}$ & 2016 Target & Ultimate Target \\
\hline Bus lifetime & years/miles & $3.5 / 102,000^{b}$ & $12 / 500,000$ & $12 / 500,000$ \\
\hline Power plant lifetime $^{c}$ & hours & $6,700^{\mathrm{d}}$ & 18,000 & 25,000 \\
\hline Bus availability & $\%$ & 66 & 85 & 90 \\
\hline Fuel fills & per day & 1 & $1(<10 \mathrm{~min})$ & $1(<10 \mathrm{~min})$ \\
\hline Bus cost $^{f}$ & $\$$ & $2,400,000^{9}$ & $1,000,000$ & 600,000 \\
\hline Power plant cost ${ }^{\mathrm{c}, \mathrm{f}}$ & $\$$ & $\mathrm{~N} / \mathrm{A}^{\mathrm{h}}$ & 450,000 & 200,000 \\
\hline $\begin{array}{l}\text { Hydrogen storage } \\
\text { cost }\end{array}$ & $\$$ & $N / A^{h}$ & 75,000 & 50,000 \\
\hline $\begin{array}{l}\text { Roadcall frequency } \\
\text { (bus/fuel cell system) }\end{array}$ & $\begin{array}{l}\text { miles between } \\
\text { roadcalls }\end{array}$ & $\begin{array}{l}3,800 / \\
21,000 \\
\end{array}$ & $\begin{array}{l}3,500 / \\
15,000 \\
\end{array}$ & $\begin{array}{l}4,000 / \\
20,000 \\
\end{array}$ \\
\hline Operation time & $\begin{array}{c}\text { hours per } \\
\text { day/days per } \\
\text { week }\end{array}$ & $\begin{array}{c}7-14 / \\
5-7\end{array}$ & $20 / 7$ & $20 / 7$ \\
\hline $\begin{array}{l}\text { Scheduled and } \\
\text { unscheduled } \\
\text { maintenance cost }\end{array}$ & \$/mile & 0.54 & 0.75 & 0.40 \\
\hline Range & miles & $280^{j}$ & 300 & 300 \\
\hline Fuel economy & $\begin{array}{l}\text { miles per diesel } \\
\text { gallon equivalent }\end{array}$ & 6.72 & 8 & 8 \\
\hline
\end{tabular}

${ }^{a}$ Summary of the results for the AFCBs in this report: data from March 2013 to June 2015.

${ }^{\mathrm{b}}$ Accumulated totals for the oldest AFCB through June 2015; these buses have not reached end of life; targets are for lifetime.

${ }^{\mathrm{c}}$ For the DOE/FTA targets, the power plant is defined as the fuel cell system and the battery system. The fuel cell system includes supporting subsystems such as the air, fuel, coolant, and control subsystems. Power electronics, electric drive, and hydrogen storage tanks are excluded.

${ }^{\mathrm{d}}$ The status for power plant hours is for the fuel cell system only; battery lifetime hours were not available.

${ }^{\mathrm{e}}$ Multiple sequential fuel fills should be possible without an increase in fill time.

${ }^{\mathrm{f}}$ Cost targets are projected to a production volume of 400 systems per year. This production volume is assumed for analysis purposes only and does not represent an anticipated level of sales.

${ }^{\mathrm{g}}$ Approximate cost of the prototype AFCB based on a very low quantity as a non-production, prototype vehicle (not including non-recurring engineering for the initial design).

${ }^{\mathrm{h}}$ Capital costs for subsystems are not currently reported by the manufacturers.

${ }^{\mathrm{i}}$ Excludes mid-life overhaul of the power plant.

${ }^{\mathrm{j}}$ Based on fuel economy and useful fuel tank capacity.

\footnotetext{
${ }^{1}$ Fuel Cell Technologies Program Record \# 12012, September 12, 2012, http://www.hydrogen.energy.gov/pdfs/12012_fuel_cell_bus_targets.pdf.
} 


\section{Table of Contents}

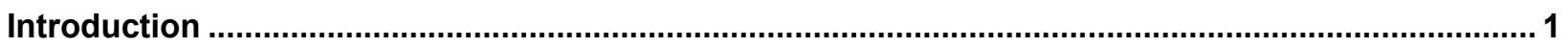

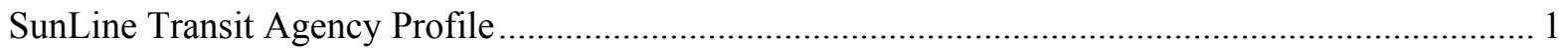

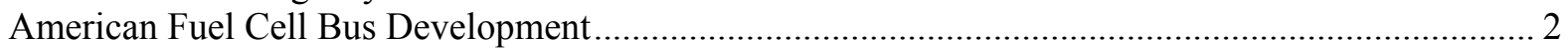

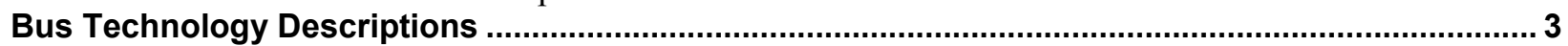

FCEB Development Process_-Technology Readiness Levels......................................................... 5

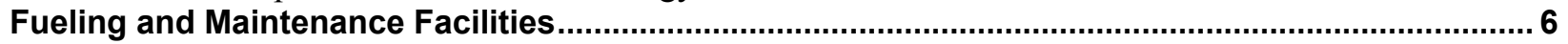

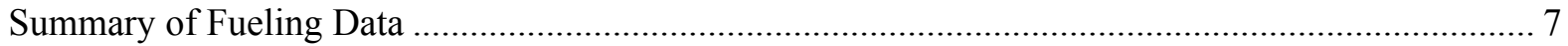

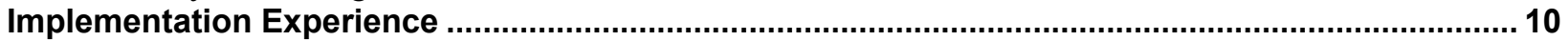

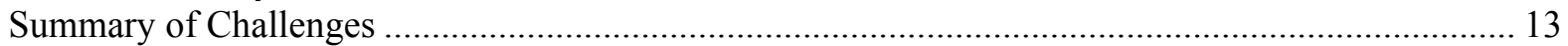

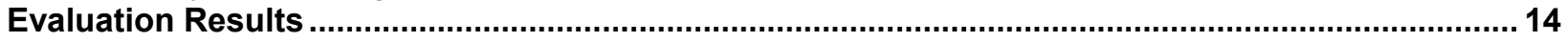

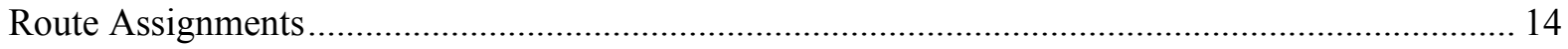

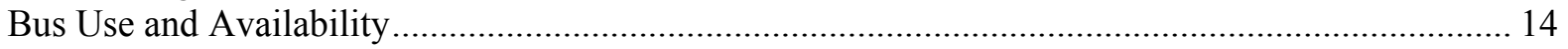

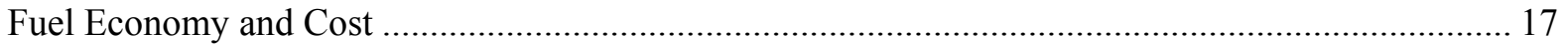

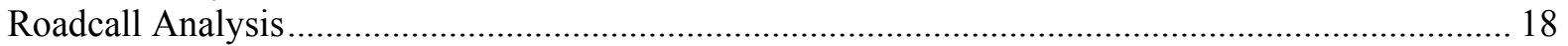

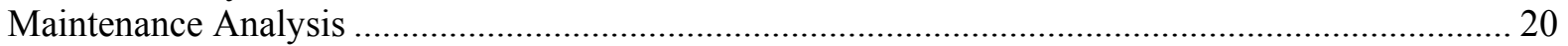

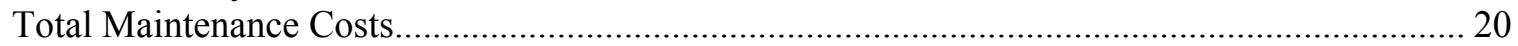

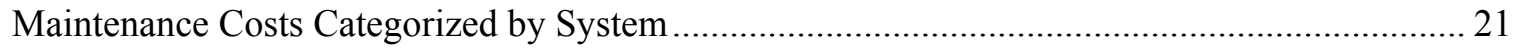

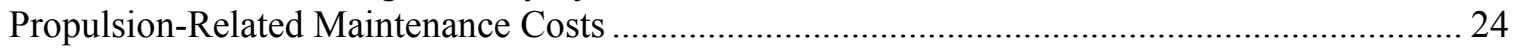

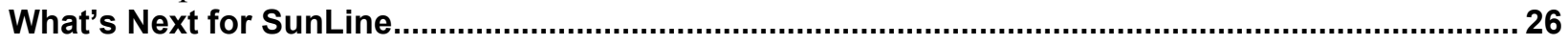

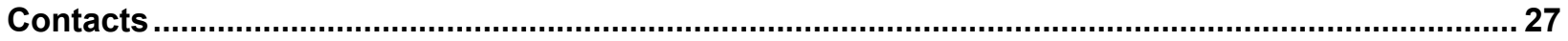

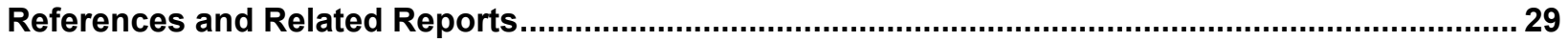

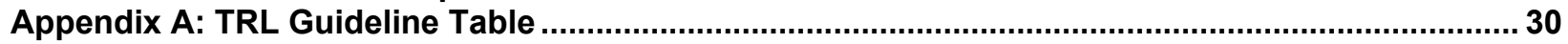

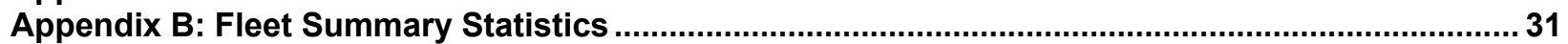

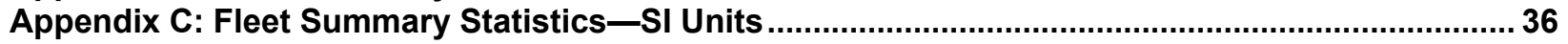




\section{Introduction}

In December 2011, SunLine Transit Agency began operating a new fuel cell electric bus (FCEB) in its service area in Southern California. This bus, called the American Fuel Cell Bus (AFCB), was developed as part of the Federal Transit Administration's (FTA) National Fuel Cell Bus Program (NFCBP). The 40-foot ElDorado National bus features a hybrid electric propulsion system by BAE Systems and a fuel cell from Ballard Power Systems. SunLine is collaborating with the U.S. Department of Energy's (DOE) National Renewable Energy Laboratory (NREL) to evaluate the bus in revenue service. NREL published a report documenting the performance and SunLine's early experience with the bus in July 2013 . $^{2}$ SunLine received two additional AFCBs in 2014 and a third in 2015. This report provides an update to the previous report and covers data collected on all four buses through June 2015.

\section{SunLine Transit Agency Profile}

SunLine Transit Agency provides public transit services to Southern California's Coachella Valley. Headquartered in Thousand Palms, California, SunLine's service area covers more than 1,100 square miles including nine member cities and a portion of Riverside County. SunLine's service area is shown in Figure 1.

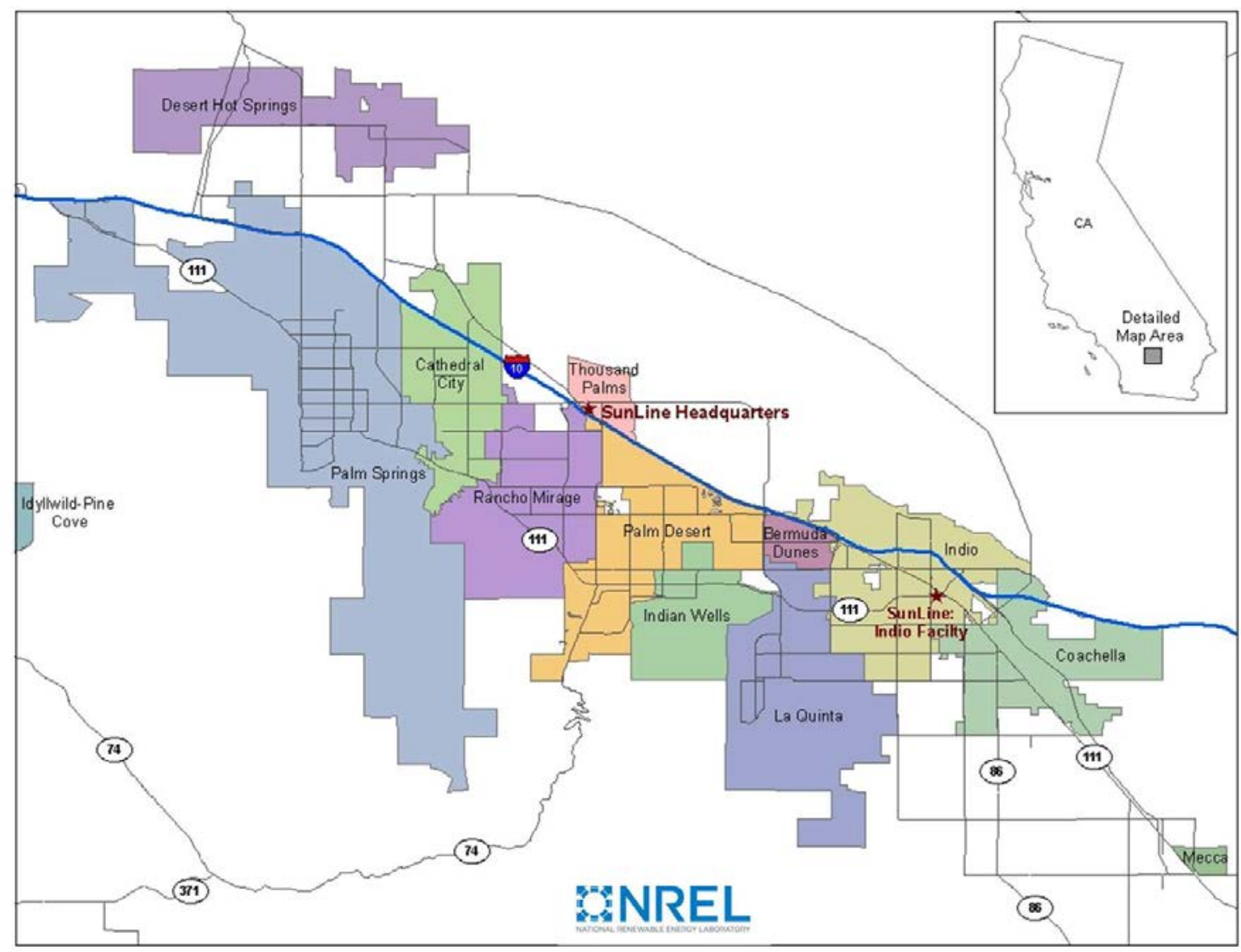

Figure 1. SunLine service area

\footnotetext{
${ }^{2}$ American Fuel Cell Bus Project: First Analysis Report, FTA Report No. 0047, June 2013, http://www.fta.dot.gov/documents/FTA_Report_No._0047.pdf.
} 
SunLine is committed to operating clean fuel technologies in its fleet, beginning with complete fleet implementation of compressed natural gas (CNG) buses in 1994. Since then, the agency has tested many advanced technologies, including buses that run on a blend of hydrogen and CNG, battery electric power, and fuel cells. SunLine is committed to advancing hydrogen and fuel cell bus technologies for transit, and the agency continues to invest time and effort into projects that will facilitate commercialization. Over the last 10 years, SunLine has operated seven different generations of buses powered by hydrogen, including FCEBs, a hydrogen-fueled internal combustion engine bus, and buses operating on a blend of CNG and hydrogen. This experience makes the agency an excellent demonstration partner.

\section{American Fuel Cell Bus Development}

FTA awarded funding to the AFCB Project in 2006 when the NFCBP was initiated. The project is managed through CALSTART, a member organization focused on commercialization of clean transportation technologies. CALSTART and SunLine brought together a team of manufacturers with the goals of developing a FCEB to advance the technology and address the challenge of 'Buy America' compliance. The AFCB design builds on the commercial series hybrid electric propulsion system developed by BAE Systems. BAE Systems served as the lead vehicle integrator and supplied the hybrid propulsion system, power converters, and electric accessories. Ballard Power Systems provided the $150 \mathrm{~kW}$ fuel cell system and ElDorado National produced the bus glider and served as the final stage manufacturer. The prototype AFCB was completed and delivered to SunLine in November 2011. The agency put the bus in service in mid-December 2011. During the first year, the bus traveled more than 48,000 miles and accumulated more than 3,000 hours on the fuel cell system. SunLine received additional funding through the NFCBP to extend support to the AFCB and another of its FCEBs for an additional 10 years.

In 2011, SunLine was awarded funding through FTA's Transit Investments for Greenhouse Gas and Energy Reduction Program (TIGGER) to add two more AFCBs to its fleet. Typically, orders for transit buses are led by the bus original equipment manufacturer (OEM). The OEM works with suppliers to provide the sub-components that are not built at its factories. At the current stage of FCEB development, the integrator and transit agency have taken the lead role in designing and building the FCEB. For FCEBs to be fully commercialized, the fuel cell hybrid propulsion system needs to be an option offered by the bus OEM. SunLine's TIGGER project enabled the manufacturer team to begin transitioning the build process to the bus OEM. The first bus glider was shipped to BAE Systems for integration of the propulsion system. BAE Systems worked with ElDorado staff to complete the installation. The second bus was entirely built at the ElDorado factory with support from BAE Systems. The team has received several more orders for AFCBs, which all are being built on the production line at ElDorado. In February 2015, SunLine received a fourth AFCB that was originally planned for another agency.

The team has built several more AFCBs for U.S. transit agencies over the last year and has more on order. Once these buses are complete there will be a total of 17 AFCBs. The new demonstration sites will provide the team with data on AFCB performance in colder climates and allow the technology to be optimized to meet the needs of any U.S. transit agency. 


\section{Bus Technology Descriptions}

The AFCB is a 40-foot ElDorado National bus with a BAE Systems hybrid electric propulsion system powered by Ballard's FCvelocity-HD6 150-kW fuel cell. Table 1 provides bus system descriptions for the AFCBs (one of which is shown in Figure 2) and the CNG buses studied in this evaluation. SunLine has assigned a designation of FC3 to its first AFCB. The two TIGGERfunded AFCBs are designated FC4 and FC5. The last bus received is designated FC6. Five CNG buses operating from the same SunLine location are being evaluated as a baseline comparison. One of the CNG buses is pictured in Figure 3. These buses are 2008 model year New Flyer CNG buses with Cummins Westport ISL G natural gas engines that are designed to meet 2010 emission regulations.

Table 1. Fuel Cell and CNG Bus System Descriptions

\begin{tabular}{|c|c|c|c|}
\hline Vehicle System & AFCB (Prototype) & AFCB (TIGGER) & CNG Bus \\
\hline Number of buses & 1 & 3 & 5 \\
\hline Bus designations & FC3 & FC4, FC5, FC6 & $\begin{array}{c}603,604,605,606 \\
608\end{array}$ \\
\hline $\begin{array}{l}\text { Bus manufacturer } \\
\text { and model }\end{array}$ & EIDorado National, Axess & EIDorado National, Axess & New Flyer \\
\hline Model year & 2011 & 2014 & 2008 \\
\hline Length/width/height & $40 \mathrm{ft} / 102$ in./140 in. & $40 \mathrm{ft} / 102 \mathrm{in.} / 140 \mathrm{in}$. & $40 \mathrm{ft} / 102 \mathrm{in.} / 130.8 \mathrm{in}$. \\
\hline Gross vehicle weight & $43,420 \mathrm{lb}$ & $43,420 \mathrm{lb}$ & $42,540 \mathrm{lb}$ \\
\hline Passenger capacity & $\begin{array}{c}37 \text { seated or } 31 \text { seated } \\
\text { with two wheelchairs; } 19 \\
\text { standees }\end{array}$ & $\begin{array}{c}37 \text { seated or } 31 \text { seated } \\
\text { with two wheelchairs; } 19 \\
\text { standees }\end{array}$ & $\begin{array}{l}39 \text { seated with no } \\
\text { wheelchairs }\end{array}$ \\
\hline Hybrid system & $\begin{array}{c}\text { BAE Systems, series } \\
\text { hybrid propulsion system, } \\
\text { HDS 200, } \\
200 \mathrm{~kW} \text { peak } \\
\end{array}$ & $\begin{array}{c}\text { BAE Systems, series } \\
\text { hybrid propulsion system, } \\
\text { HDS } 200 \text { Series E, } \\
200 \mathrm{~kW} \text { peak }\end{array}$ & N/A \\
\hline Fuel cell or engine & $\begin{array}{l}\text { Ballard FCvelocity }{ }^{3} \text {-HD6, } \\
150 \mathrm{~kW}\end{array}$ & $\begin{array}{l}\text { Ballard FCvelocity-HD6, } \\
150 \mathrm{~kW}\end{array}$ & $\begin{array}{l}\text { Cummins Westport } \\
\text { ISL G } 280 \text { hp @ } \\
2,200 \text { rpm }\end{array}$ \\
\hline Energy storage & $\begin{array}{c}\text { A123, Nanophosphate } \\
\text { Li-ion; } \\
200 \mathrm{~kW}, 11 \mathrm{kWh}\end{array}$ & $\begin{array}{c}\text { A123, Nanophosphate } \\
\text { Li-ion; } \\
200 \text { kW, } 11 \text { kWh }\end{array}$ & N/A \\
\hline Accessories & Electric & Electric (APS3) & Mechanical \\
\hline Fuel capacity & $\begin{array}{l}\text { Gaseous hydrogen, } 8 \\
\text { Luxfer-Dynetek cylinders, } \\
50 \mathrm{~kg} \text { at } 350 \text { bar }\end{array}$ & $\begin{array}{c}\text { Gaseous hydrogen, } 8 \\
\text { Luxfer-Dynetek cylinders, } \\
50 \mathrm{~kg} \text { at } 350 \text { bar }\end{array}$ & $\begin{array}{l}125 \text { diesel gallon } \\
\text { equivalent }\end{array}$ \\
\hline Bus purchase cost & $\$ 2.4$ million $^{4}$ & $\$ 2.1$ million- $\$ 2.4$ million $^{5}$ & $\$ 402,900$ \\
\hline
\end{tabular}

\footnotetext{
${ }^{3}$ FCvelocity is a registered trademark of Ballard Power Systems.

${ }^{4}$ Approximate cost of the prototype AFCB based on a very low quantity as a non-production, prototype vehicle (not including non-recurring engineering for the initial design).

${ }^{5}$ Range of costs for the AFCBs produced during the same timeframe as FC4, FC5, and FC6.
} 


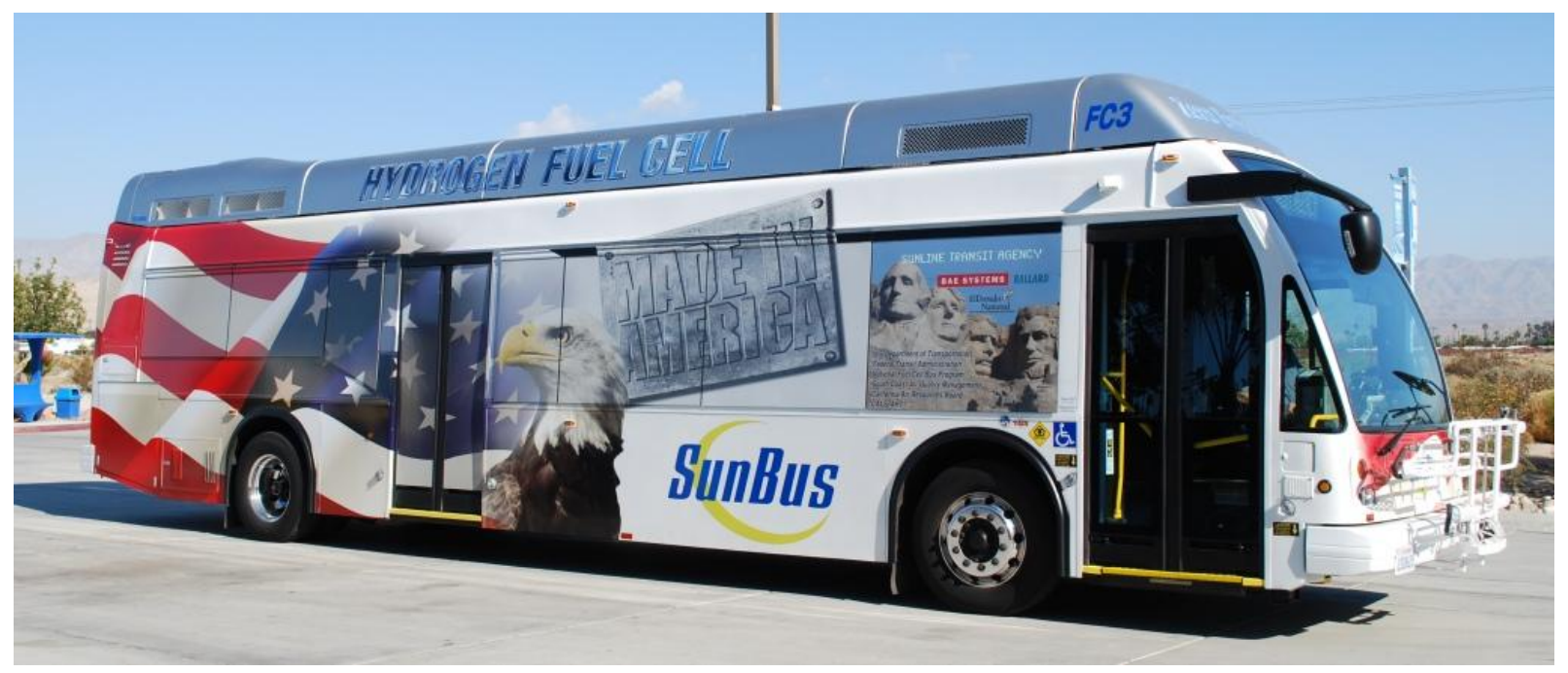

Figure 2. SunLine American Fuel Cell Bus

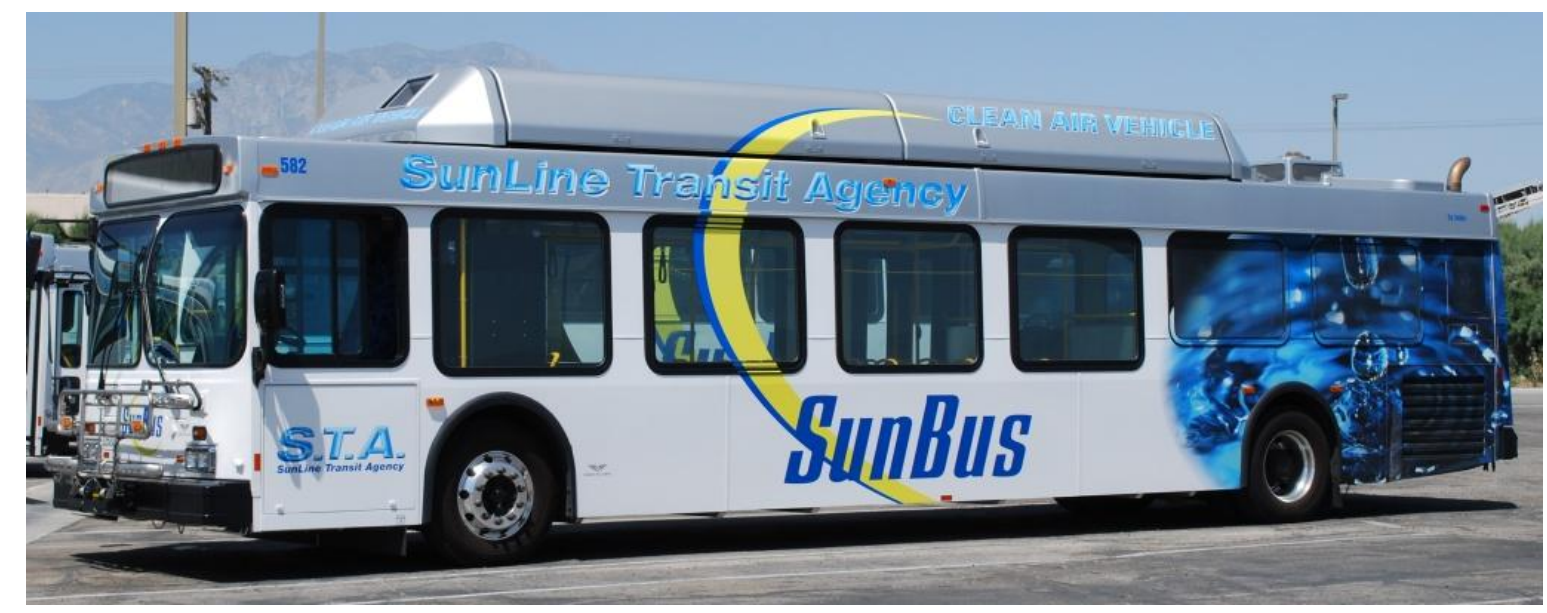

Figure 3. SunLine CNG bus

BAE Systems based the prototype AFCB propulsion system on its commercial hybrid electric transit bus product, which is operating in buses around the world. For the AFCB, the system was modified to provide power with the Ballard fuel cell system in place of a diesel engine/generator. Ballard's 150-kW fuel cell incorporates the latest advances for durability and efficiency based on numerous field demonstrations of Ballard fuel-cell-powered buses. The AFCB also incorporates a suite of electric accessories powered by BAE Systems' Accessory Power System.

The manufacturer team used the early demonstration experience of the prototype bus to make modifications and updates to the system for the next AFCBs. While the basic design components are the same as that of the prototype, the newer buses feature refinements that should make servicing easier and increase reliability. Many of the changes were designed to create a commonality across BAE Systems' hybrid platform. Changes include the following:

- Separate cooling system for the batteries (instead of using air conditioning)

- Improved tubing and joints in the cooling system to alleviate potential leaks 
- Larger coolant pump to the fuel cell

- Simplified power conversion system

- Upgraded radiator cradle design to increase integrity

- Software updates.

\section{FCEB Development Process-Technology Readiness Levels}

NREL has developed a guideline for assessing the technology readiness level (TRL) for FCEBs. ${ }^{6}$ Figure 4 provides a graphic representation of this process. (Appendix A provides the TRL guideline table tailored for FCEB commercialization.) The guideline considers the FCEB as a whole and does not account for differing TRLs for separate components or sub-systems. Some sub-systems may include off-the-shelf components that are considered commercial, while other sub-systems may feature newly designed components at an earlier TRL.

\section{Commercialization Process}

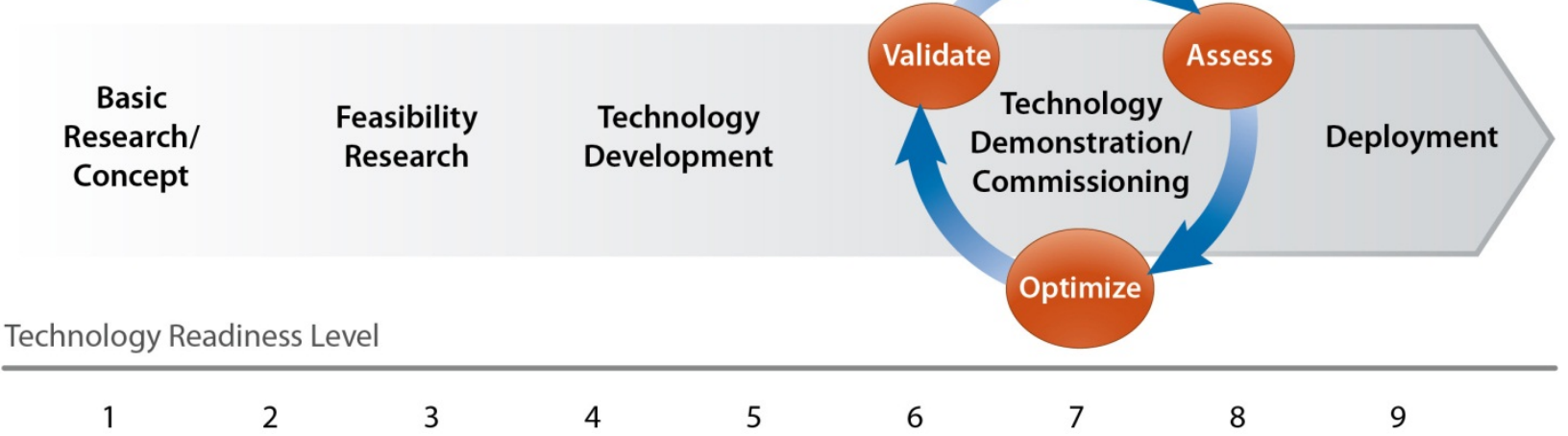

Figure 4. Graphic representation of the commercialization process developed for FCEBs

FCEB development is currently in the technology demonstration/commissioning phase that includes TRLs 6 through 8. This phase begins the iterative process to validate the design, analyze the results, and reconfigure or optimize the design as needed. The manufacturer typically works with a transit agency partner to conduct in-service tests on the bus. Updates to the design are made based on the performance results, and the buses go back into demonstration and through the cycle until the design meets the performance requirements. This can be a time-consuming process as manufacturers work through technical difficulties.

NREL considers the AFCB to be in the beginning stage of TRL 7 because the design of the bus was led by manufacturers experienced with FCEB and hybrid technology development and the deployment will include more than 10 buses in various locations. These buses represent a fullscale validation in a relevant environment. At this point in the development, FCEBs are not commercial products. The manufacturers' goals for the demonstration are to verify that the FCEB performance meets the DOE/FTA technical targets and identify any issues that need to be resolved. The current costs for FCEB technology — both capital and operating costs - are still much higher than that of conventional diesel and CNG technology. This is expected considering diesel and CNG are very mature technologies (TRL 9) and FCEBs are still in the development

\footnotetext{
${ }^{6}$ Fuel Cell Buses in U.S. Transit Fleets: Current Status 2012, NREL/TP-5600-56406, November 2012, http://www.nrel.gov/docs/fy13osti/56406.pdf.
} 
stage. Once an advanced technology, such as FCEBs, meets the performance targets, the industry can work to reduce costs. This was the case with both compressed natural gas and diesel-hybrid bus technologies when they were first developed.

NREL's goal in evaluating FCEBs is to document the performance and track progress over time toward meeting the technical targets. NREL collects data on conventional buses at each demonstration site for a baseline comparison. This is important primarily because fuel economy is highly dependent on duty cycle, but also because maintenance practices can be different from site to site. The best comparisons need to include buses operated in similar service at the same operating division. For the evaluation at SunLine, NREL collects data on CNG buses for a baseline comparison to the FCEBs. SunLine does not operate any diesel buses.

\section{Fueling and Maintenance Facilities}

SunLine owns and operates a fueling station that supplies fuel for its fleet as well as to the public. The station offers $\mathrm{CNG}$, a blend of $\mathrm{CNG}$ and hydrogen, and pure hydrogen. $\mathrm{CNG}$ is brought to the SunLine property via a high-pressure natural gas line and then compressed to 3,600 psi for dispensing into the vehicles. SunLine produces hydrogen onsite using a natural gas reformer. SunLine typically operates the reformer at $4.5 \mathrm{~kg}$ per hour to meet current hydrogen demand, although the unit is capable of producing up to $9 \mathrm{~kg}$ of hydrogen per hour. Onsite storage of hydrogen is approximately $180 \mathrm{~kg}$ of hydrogen compressed to 6,000 psi for dispensing into the buses at 5,000 psi. SunLine estimates that this hydrogen fueling infrastructure can produce enough hydrogen to comfortably operate five full-size transit buses without running out of fuel for the smaller hydrogen fuel cell light-duty vehicles expected to be fueled at this station. Now that SunLine is operating five FCEBs, the agency is in the process of upgrading the station to produce and store a larger quantity of hydrogen. Figure 5 shows the first AFCB at the fueling station.

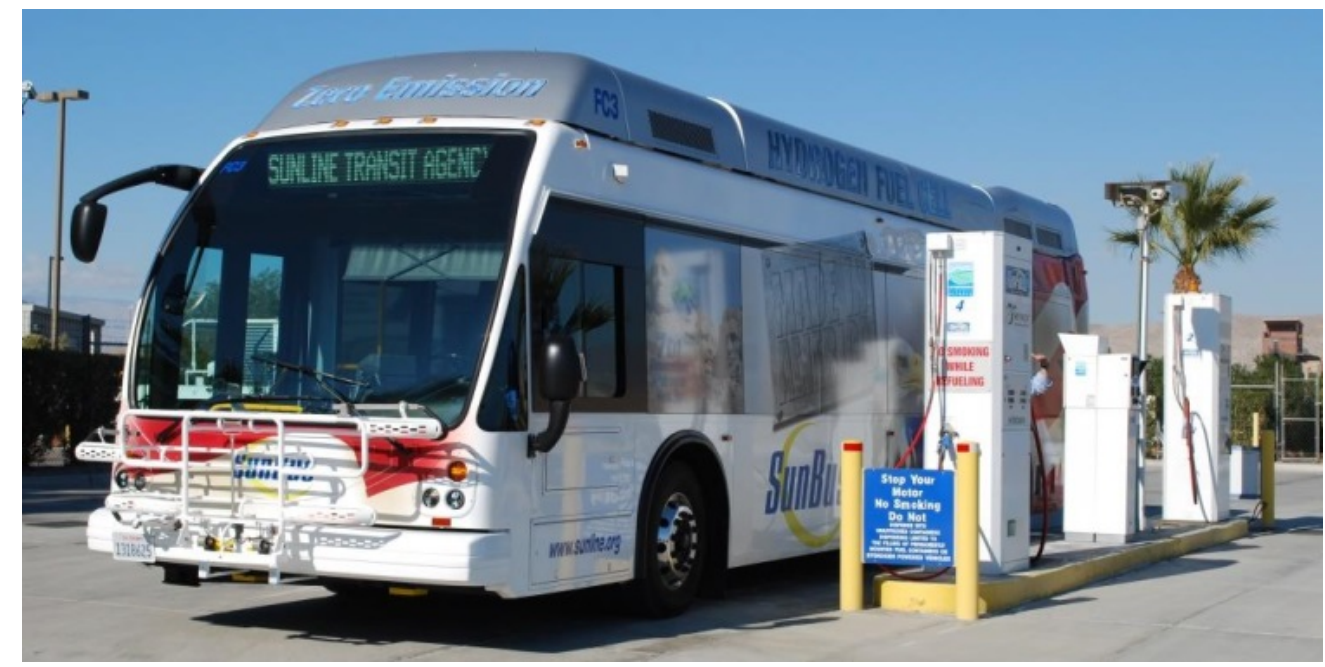

Figure 5. AFCB at SunLine's fueling station

SunLine tracks all of its fueling events in gasoline gallon equivalent (GGE) units to comply with state fuel-sale regulations. For hydrogen, the unit used is typically kilograms — one kg of hydrogen contains essentially the same energy as one GGE for fuel economy calculations. This report presents results in both GGE (kg for hydrogen) and diesel gallon equivalent (DGE) for 
hydrogen and CNG fuel consumption. The end of Appendix B shows the energy-conversion calculations for GGE and DGE.

SunLine's maintenance facility (Figure 6) is configured for maintaining both CNG- and hydrogen-fueled buses. SunLine staff members are experienced with hydrogen and fuel cell buses and handle much of the maintenance on the AFCBs. Both BAE Systems and Ballard have the capability to remotely monitor bus performance. This aids in troubleshooting and eliminates the need for permanent on-site support from the manufacturers. SunLine can call on the local BAE Systems sales and service office for support with the hybrid system. SunLine staff members do all of the preventive maintenance on the fuel cell systems and use a diagnostic tool to aid in troubleshooting any issues. They also handle most of the repair work on the fuel cells but can call on a Ballard technician if needed.

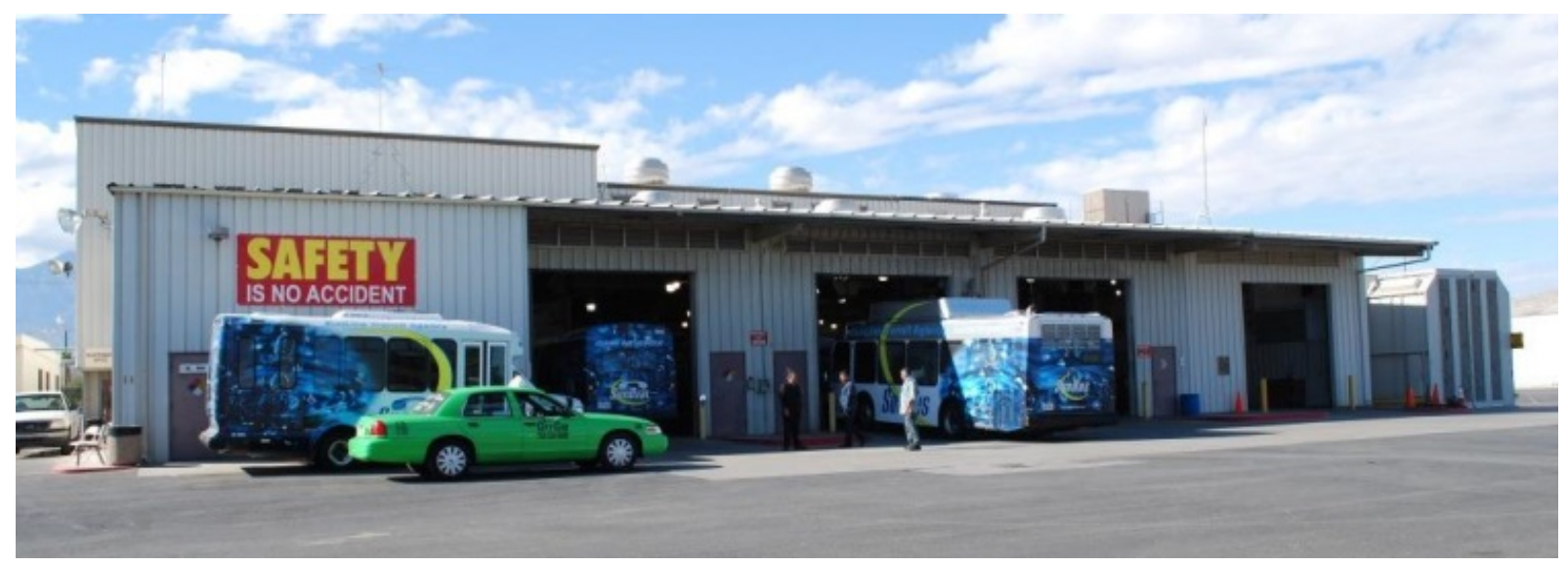

Figure 6. SunLine's maintenance facility

\section{Summary of Fueling Data}

During the majority of the data collection period, SunLine operated two fuel cell buses in its service area: the prototype AFCB and a New Flyer fuel cell bus (AT FCEB). The three new AFCBs were placed into service in 2014 and 2015. To show overall performance of the station, the fueling analysis figures include total hydrogen dispensed from the station into all five of the buses. Figure 7 shows the average daily hydrogen dispensed into SunLine's fuel cell buses from December 2011 through June 2015. The station was used at least once per day to fill at least one hydrogen bus for $78 \%$ of the calendar days during the period. The overall average daily use was $34.6 \mathrm{~kg}$ per day. During this period, SunLine dispensed a total of 35,050 kg of hydrogen. The months with the lowest hydrogen dispensed had downtime for one bus or another during that month. By the end of the data period, SunLine had five buses in service (four AFCBs and the AT FCEB). The data show increased amounts of hydrogen use during this time. 


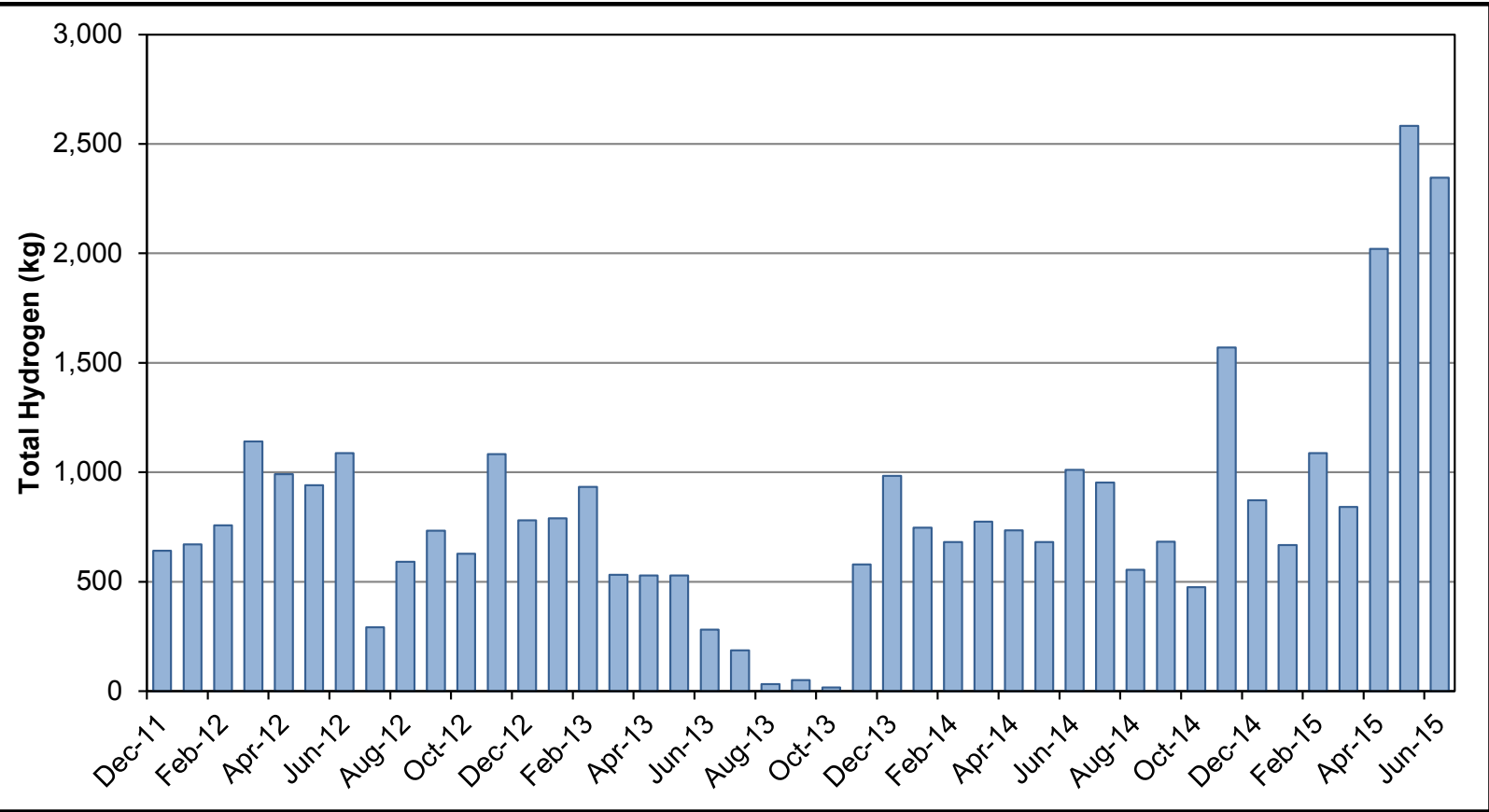

Figure 7. Average hydrogen dispensed per day (excluding 0 kg days)

Figure 8 shows the distribution of hydrogen amounts dispensed per fill. The buses were filled a total of 1,481 times during the evaluation period for a total of 31,224 kg hydrogen. ${ }^{7}$ The average amount of hydrogen per fill was $22.1 \mathrm{~kg}$. Figure 9 shows a cumulative fueling rate histogram for the SunLine hydrogen station from December 2011 through June 2015. The overall average fueling rate was $0.96 \mathrm{~kg}$ per minute, and the average time for a fill was approximately 22 minutes.

\footnotetext{
${ }^{7}$ This total is slightly lower than discussed above. If the time for the fueling was not captured in data collection, that fueling data point was excluded for this calculation.
} 


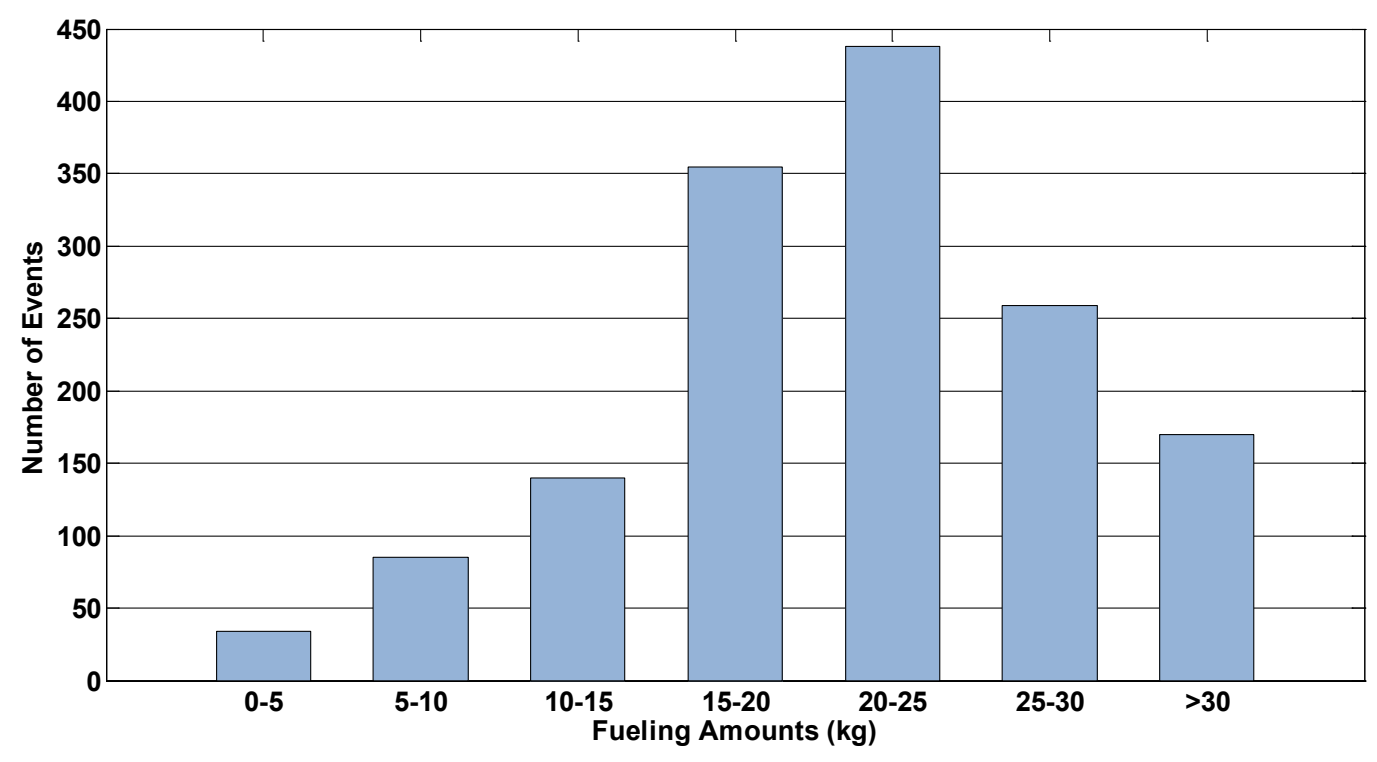

Figure 8. Histogram of fueling amounts

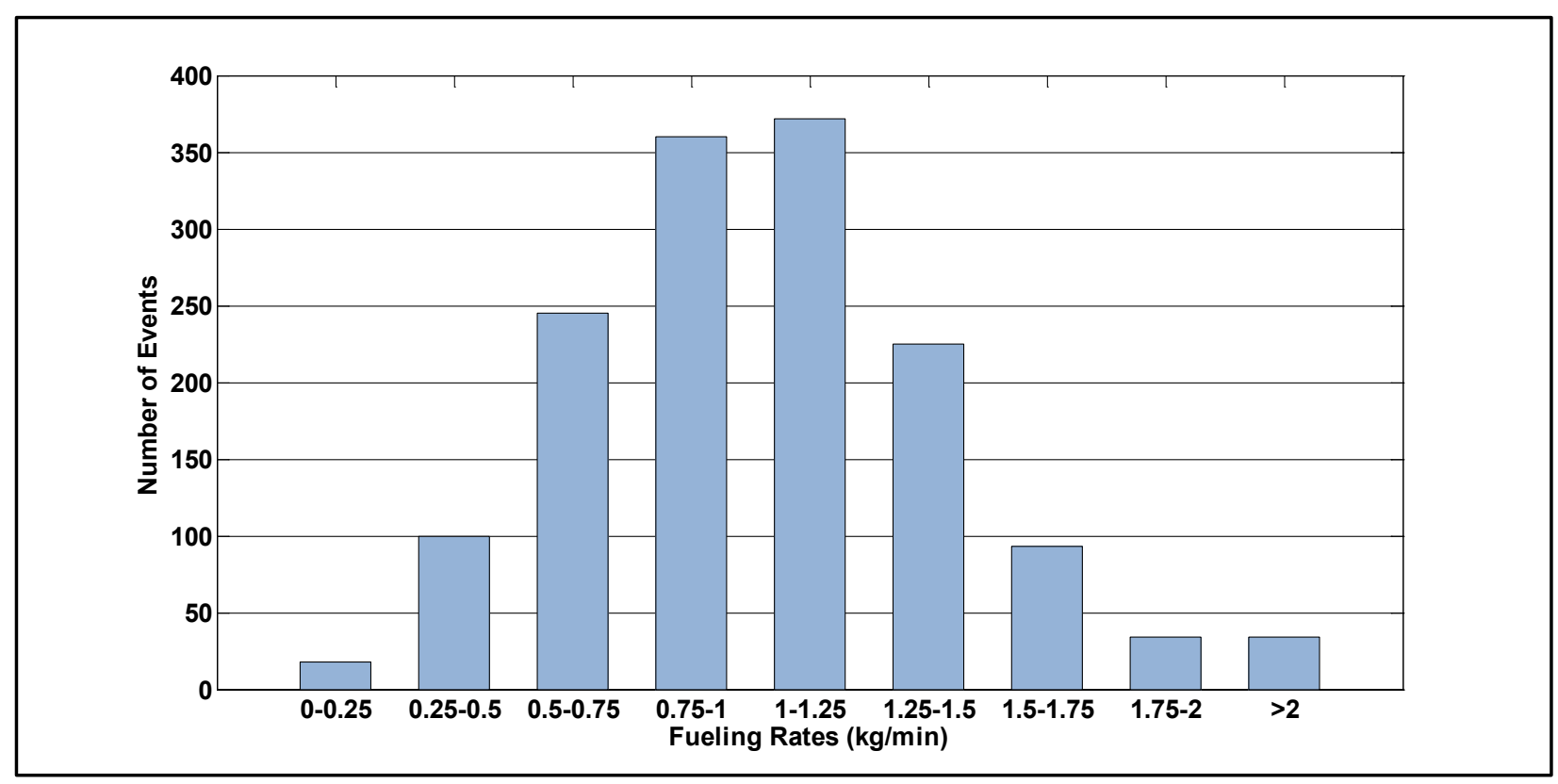

Figure 9. Histogram of fueling rates

Hydrogen fuel costs at SunLine consist of the cost of natural gas for the reformer, the cost for maintenance of the station equipment, and capital cost amortization. SunLine performs the maintenance of the station equipment, including parts and labor. The average monthly cost for hydrogen at SunLine varies based on total hydrogen dispensed and station maintenance costs. Figure 10 shows the monthly kilograms dispensed and cost per kilogram of hydrogen from July 2013 through May 2015. During the data period, the agency has seen costs from as low as $\$ 5.37 / \mathrm{kg}$ to more than $\$ 1,000 / \mathrm{kg}$. The months when the station sees its highest use have the lowest cost per kilogram. In August 2013, the hydrogen cost was more than $\$ 1,099 / \mathrm{kg}$. During that month SunLine replaced a failed chiller unit in the reformer, which resulted in a higher 
maintenance cost. From July 2013 through October 2013, SunLine's AFCB was not operating. Once the bus was back in service, the station use increased. By April 2015, SunLine had four buses operating. The average cost of hydrogen during the period from November 2013 through May 2015 was $\$ 13.47 / \mathrm{kg}$. SunLine estimates that the best steady-state operating point for the reformer system would bring the average cost of hydrogen to around $\$ 8 / \mathrm{kg}$. This cost estimate is used in the cost calculations for the data results in the next section.

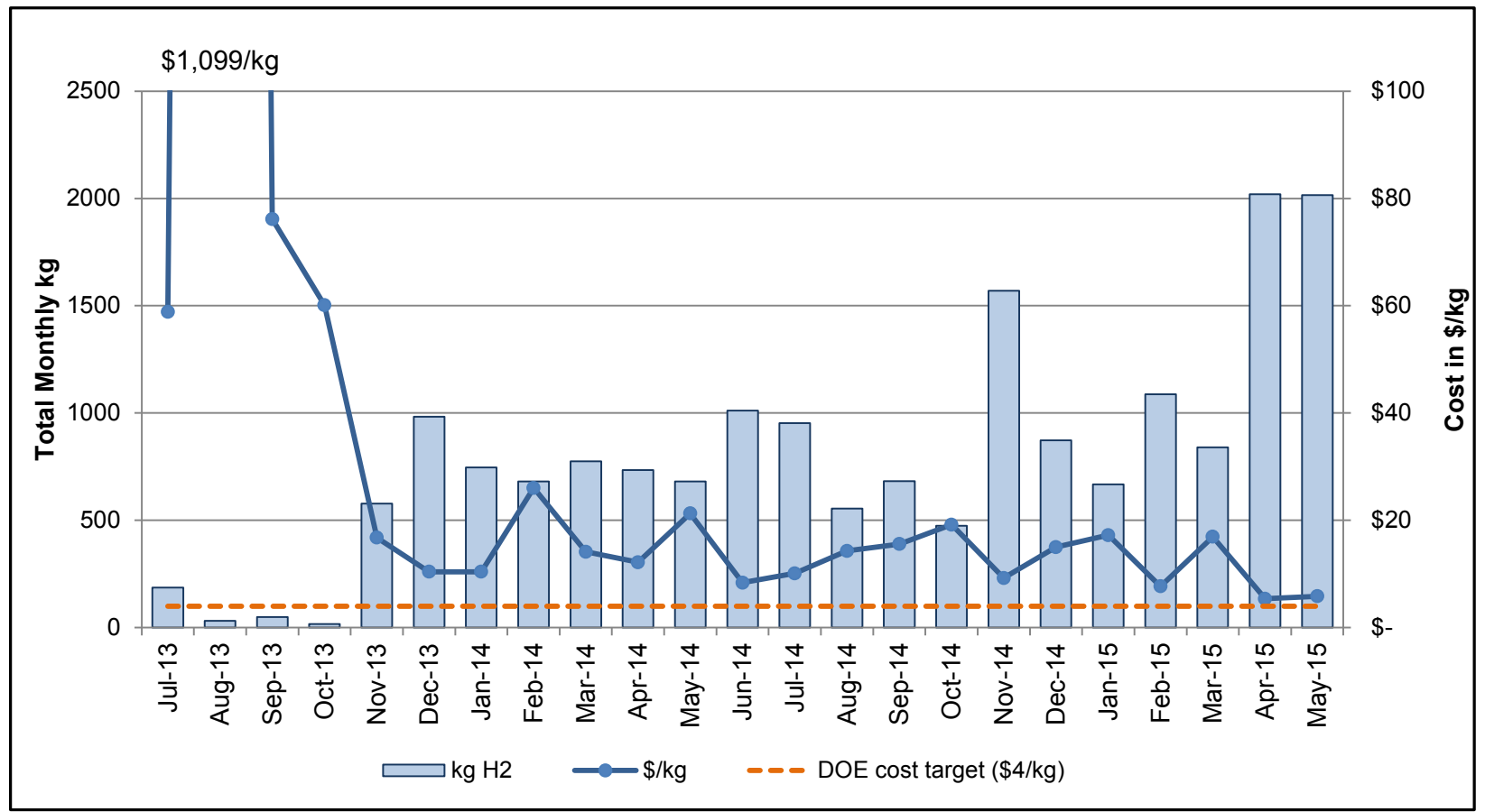

Figure 10. Total hydrogen dispensed and cost per kilogram by month

The average CNG price at the dispenser for SunLine (not the public price) during the data period was \$0.99 per GGE. This price includes all costs — natural gas, maintenance, and station amortization. SunLine supplies CNG fuel to users in its area, and the fueling station is accessible to the public. The high volume of natural gas use has allowed SunLine to command a low cost as a commodity user.

\section{Implementation Experience}

The prototype AFCB (FC3) was delivered in November 2011 and was put into service by midDecember. For each evaluation, NREL works with the project partners to determine a starting point - or clean point - for the data analysis period. The clean point is chosen to avoid some of the early and expected operations problems with a new vehicle going into service, such as early maintenance campaigns. In some cases, reaching the clean point may require 3 to 6 months of operation before the evaluation can start. For the prototype AFCB, the clean point began in March 2012. From that time point through the first year of demonstration, the bus performed extremely well. After February 2013, the bus developed a few issues that required some downtime for diagnosis and repair. These issues are documented later in this section. The first of the TIGGER buses (FC4) was delivered in April 2014 and placed into service in June 2014. The second TIGGER bus (FC5) was delivered in June 2014 and went into service in August 2014. The buses have experienced a few start-up issues that are being resolved. At this point, the clean 
point for FC4 is June 2014 and the clean point for FC5 is December 2014. The third new AFCB (FC6) was delivered in February 2015 and went into service in May 2015. The bus has performed well in its first two months of service and the data are included in the analysis.

Since the last report, there have been multiple accomplishments.

- Three new AFCBs have been delivered and placed into revenue service

- The four AFCBs have operated 151,935 miles and accumulated 10,297 hours on the fuel cell power systems since being placed into service

- SunLine has safely fueled its FCEBs 1,097 times with more than 22,900 $\mathrm{kg}$ of hydrogen during the data period ${ }^{8}$

- The prototype AFCB has surpassed 6,700 hours on the fuel cell power system.

Progress toward AFCB commercialization-The manufacturer team continues to work toward full commercialization of the AFCB design with a goal of offering a fuel cell electric bus as a standard option along with other propulsion technologies. BAE Systems has aligned the AFCB design with its commercial hybrid electric propulsion platform. With this standardization, the fuel cell is just another way to power the propulsion system as opposed to a diesel engine. Any updates to the standard hybrid system gets rolled out to all systems. This standardization will facilitate the ability of BAE Systems' current service centers to provide support to AFCB customers as needed.

BAE Systems, Ballard, and ElDorado are working with the Center for Transportation and the Environment to develop a comprehensive maintenance manual for the AFCB. The team is using the early experience with the prototype bus to build a database of maintenance items. This database is being used to develop a troubleshooting guide and diagnostic tools to aid transit agencies in determining issues and repairing the buses. The manual and diagnostic tools will be helpful to other transit agencies interested in introducing the technology and are an important step in commercialization.

Public awareness-SunLine promotes its clean technology buses to the public. For each of the previous-generation FCEBs, SunLine designed a graphic wrap to highlight the benefits of the advanced technology being demonstrated and to help educate the public. The wrap for the prototype AFCB highlighted that the bus produced zero emissions and was built in America. The wrap featured the American flag, a bald eagle, and Mount Rushmore (see Figure 11).

\footnotetext{
${ }^{8}$ Data totals include five FCEBs operated at SunLine: the four AFCBs and another FCEB of a different design.
} 


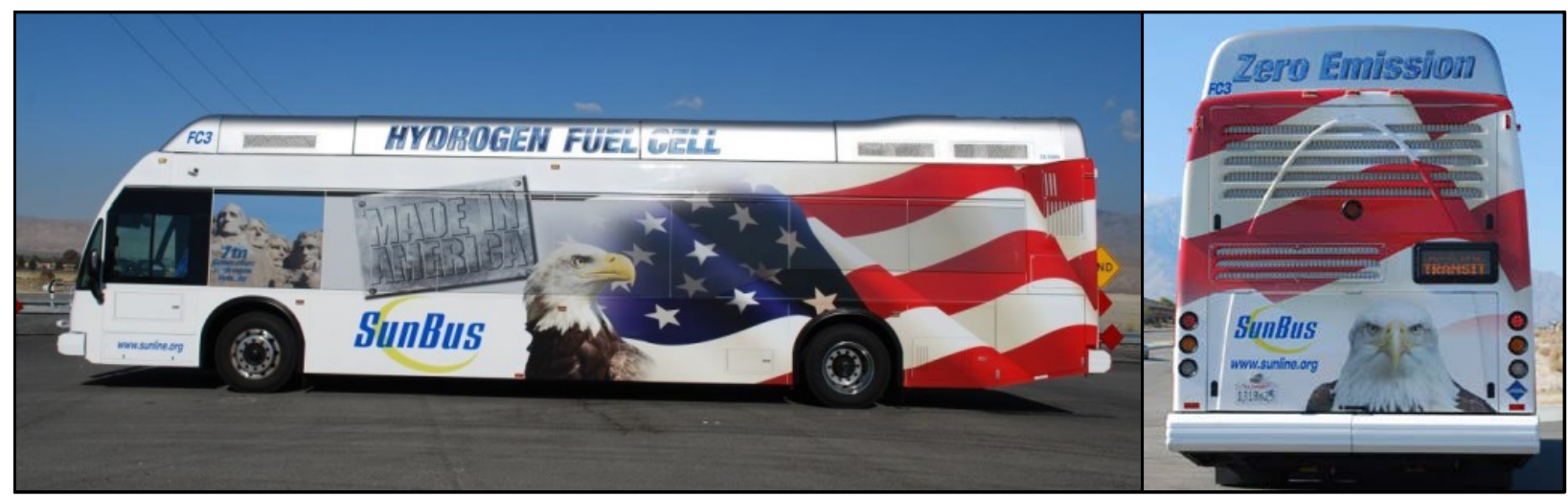

Figure 11. SunLine's first AFCB with 'Made in America' graphics

For the two new buses, SunLine partnered with the Desert Regional Medical Center to develop the bus wraps that included artwork from local school students. SunLine held two art contestsone for elementary school students and one for middle school students - to select the artwork for the two buses. The theme for the contest was "SunLine buses are good for the Coachella Valley and the environment." SunLine and the Desert Regional Medical Center held an event to unveil the new buses and honor the art contest winners in June 2014. Figure 12 shows the two new buses with the contest winners' artwork centered on the wraps.

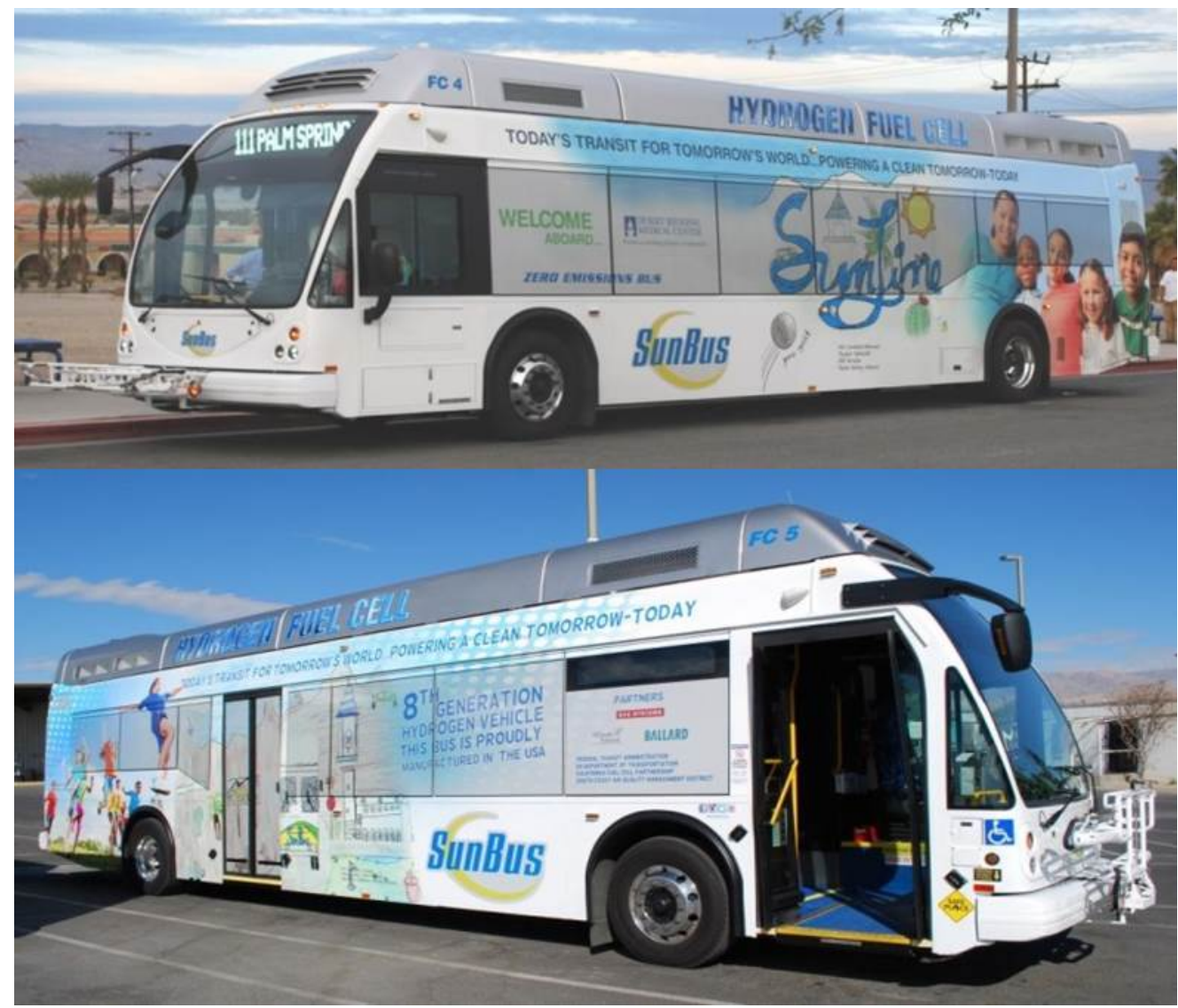

Figure 12. SunLine's new AFCBs feature artwork from local school students 


\section{Summary of Challenges}

Advanced technology demonstrations typically experience challenges and issues that need to be resolved. A few of the issues and status of resolution are provided here.

Fuel cell balance of plant issues - The majority of issues related to the fuel cell system have been with the balance of plant. One problem was with the cold start pump for the fuel cell. This pump takes coolant from the main cooling system, which interrupts the flow. The interruption creates bubbles in the line and causes the pump to fault. The buses have also had an issue with thermal expansion in the cooling loop. The system was losing a half gallon of fluid each day. To address this issue, BAE Systems redesigned the reservoir and adjusted the coolant level to allow for expansion. One bus also experienced a fault in the motor for the air handling system. This repair was facilitated by Ballard's lessons learned through other FCEB demonstrations.

Radiator leak-The prototype bus operated extremely well from the time it was placed into service up until March 2013 when it developed a coolant leak. The leak was eventually traced to a cracked radiator. The availability of the bus dropped from March through July 2013 as SunLine tried to solve the issue. The bus could operate during this time; however, maintenance staff needed to closely monitor and add fluid on a daily basis. In August, the agency pulled the bus from service to make a concentrated effort to locate and finally repair the problem. The leak proved challenging to locate partly because of SunLine's location in the desert region of the Coachella Valley. The hot climate meant the usual method of diagnosing a leak - through visual evidence - was difficult because any pooled liquid quickly evaporated. Another factor that created a challenge was that the radiator was on the roof of the bus and was shrouded, making access difficult. Also, the members of the project team were past the original contract period and were in negotiations for the follow-on work. All of these factors contributed to the difficulty and led to the extended downtime. The bus was out of service for 3 months. Prior to the issue, the bus had an average availability of $85 \%$. Once the new contracts were in place the team took a systematic approach to troubleshoot, identify, and repair the issue. To eliminate this problem, the new AFCBs have an upgraded radiator cradle to increase integrity.

Battery issues - During integration and early testing of the prototype bus, the team pushed the operation of the batteries very hard to help understand any limitations to the system. System temperatures were higher than expected during this time, which could have resulted in damage to the batteries. BAE Systems elected to refresh the battery pack while the bus was down for the radiator leak.

Tank valve failure-One bus experienced issues with a hydrogen tank valve. SunLine staff had issues verifying that the tank was empty before replacing the failed valve, which resulted in extended downtime.

Windshield replacement_-ElDorado's Axess bus platform features a large, curved front windshield as opposed to a flat, two-piece windshield typical of older-design buses. The prototype AFCB was out of service for a month to replace its windshield after it had been cracked. SunLine received the new windshield quickly, but installation proved to be challenging compared to what they were accustomed to. The replacement windshield was broken during installation and the agency had to order another. When the second windshield arrived at ElDorado, it was already broken, which delayed the repair even longer. ElDorado worked with 
SunLine on the differing technique needed for installing a large, one-piece windshield. The downtime for this repair is considered a training issue and would be a similar challenge for any bus with a large windshield.

\section{Evaluation Results}

This report focuses on the most recent operating data collected on the fuel cell and CNG buses from March 2013 through June 2015. As mentioned previously, the data analysis for each bus began at a designated clean point after the bus went into service. For this 28-month period, FC3 operated during the entire time, FC4 operated for 12 months, FC5 operated for 7 months, and FC6 operated for only 2 months. Appendix B provides a summary of all data. Appendix C provides a data summary in SI (metric) units.

\section{Route Assignments}

SunLine's service consists of 13 fixed routes and one commuter route to Riverside. In general, SunLine's buses are randomly dispatched on its local routes. The overall system average speed is $17.6 \mathrm{mph}$ (not including the commuter route). Table 2 summarizes the route use for the AFCBs and the CNG baseline buses during the evaluation period. The AFCBs were used primarily on Line $111(73 \%)$ with some additional service on Line $53(9 \%)$ and Line $30(10 \%)$. The overall average speed for the AFCBs was $16.8 \mathrm{mph}$. The five CNG buses were randomly dispatched with the majority (86\%) of time split between Line 111, Line 14, and Line 30. Based on the dispatching information, the CNG buses operated at a slightly lower average speed (16.3 $\mathrm{mph})$ than the fuel cell buses did during the evaluation period.

Table 2. Summary of Route Use for the AFCBs and CNG Buses (Evaluation Period)

\begin{tabular}{|c|c|c|}
\hline Route & $\begin{array}{c}\text { Percent of } \\
\text { Time }\end{array}$ & $\begin{array}{c}\text { Average } \\
\text { Speed (mph) }\end{array}$ \\
\hline AFCB & \multicolumn{3}{|l|}{} \\
\hline 111 & 73 & 17.4 \\
\hline 53 & 9 & 18.4 \\
\hline 30 & 10 & 13.2 \\
\hline Average & - & 16.8 \\
\hline CNG \\
\hline 111 & 47 & 17.4 \\
\hline 14 & 20 & 17.7 \\
\hline 30 & 19 & 13.2 \\
\hline Average & - & 16.3 \\
\hline
\end{tabular}

\section{Bus Use and Availability}

This section summarizes bus usage and availability for the AFCBs and CNG buses. Bus use and availability are indicators of reliability. Lower bus usage may indicate downtime for maintenance or purposeful reduction of planned work for the buses.

Table 3 and Figure 13 summarize average monthly mileage for the buses through June 2015 . Using the CNG buses as the baseline, the AFCBs had an average monthly mileage that was about half that of the CNG buses. During the data period, several issues with FC3 resulted in 
extended downtime. Most of the issues were related to bus systems. The difficulty of troubleshooting the radiator leak resulted in extended downtime from July through November 2013. The bus was also out of service for an entire month to replace a broken windshield. The AFCBs averaged about 8 hours in service each day but achieved as many as 20 hours in a single day.

Table 3. Average Monthly Mileage (Evaluation Period)

\begin{tabular}{|c|c|c|c|c|c|}
\hline Bus & $\begin{array}{c}\text { Starting } \\
\text { Hubodometer }\end{array}$ & $\begin{array}{c}\text { Ending } \\
\text { Hubodometer }\end{array}$ & Total Mileage & Months & $\begin{array}{c}\text { Monthly } \\
\text { Average }\end{array}$ \\
\hline FC3 & 49,028 & 102,583 & 53,555 & 28 & 1,913 \\
\hline FC4 & 1,704 & 33,918 & 32,214 & 12 & 2,685 \\
\hline FC5 & 221 & 16,892 & 16,671 & 7 & 2,382 \\
\hline FC6 & 159 & 6,666 & 6,507 & 2 & 3,254 \\
\hline Total AFCB & & & $\mathbf{1 0 2 , 4 4 0}$ & $\mathbf{4 9}$ & $\mathbf{2 , 0 9 1}$ \\
\hline 603 CNG & 243,733 & 376,259 & 132,526 & 28 & 4,733 \\
\hline 604 CNG & 232,625 & 373,069 & 140,444 & 28 & 5,016 \\
\hline 605 CNG & 222,323 & 353,637 & 131,314 & 28 & 4,690 \\
\hline 606 CNG & 234,696 & 366,283 & 131,587 & 28 & 4,700 \\
\hline 608 CNG & 242,191 & 376,760 & 134,569 & 28 & 4,806 \\
\hline Total CNG & & & $\mathbf{6 7 0 , 4 4 0}$ & $\mathbf{1 4 0}$ & $\mathbf{4 , 7 8 9}$ \\
\hline
\end{tabular}

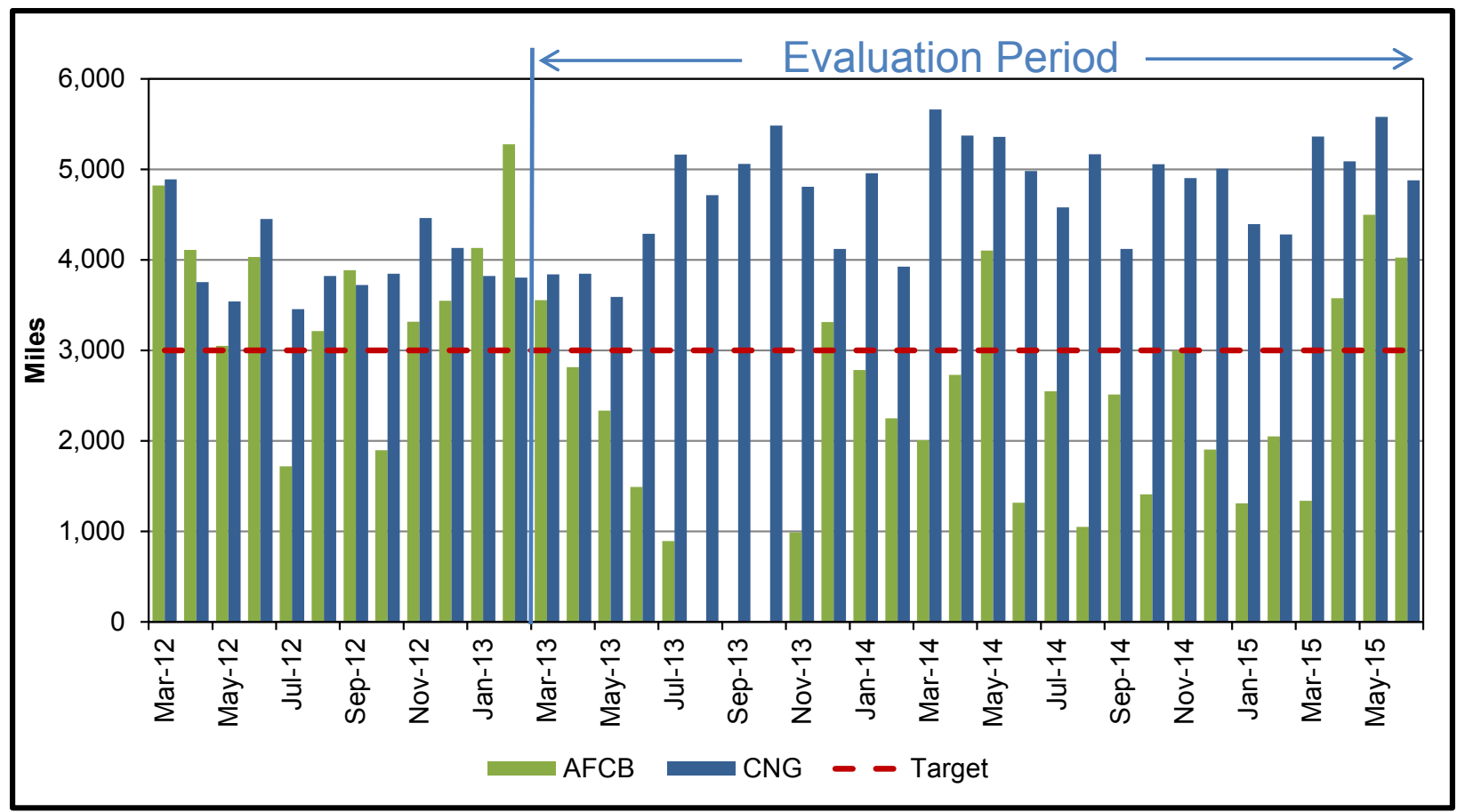

Figure 13. Monthly mileage for the AFCBs and CNG buses

Availability is the percentage of days that the buses are available for operation out of the days the buses are actually planned for operation. Availability for all of NREL's evaluations is calculated by including the planned service days, which are typically every weekday. Weekends and holidays are included in the calculation only if the bus operated in service on those days. If a bus does not operate on the weekend or on a holiday, it is not counted as unavailable. This 
strategy applies to both the AFCBs and the CNG buses. Figure 14 presents the overall monthly availability for the AFCBs and the CNG buses. The stacked bars show the total number of days the AFCBs were unavailable each month by primary system category. As shown in the chart, the availability goal is 85 percent for all buses. The chart also shows the availability for the fuel cell system as a separate line.

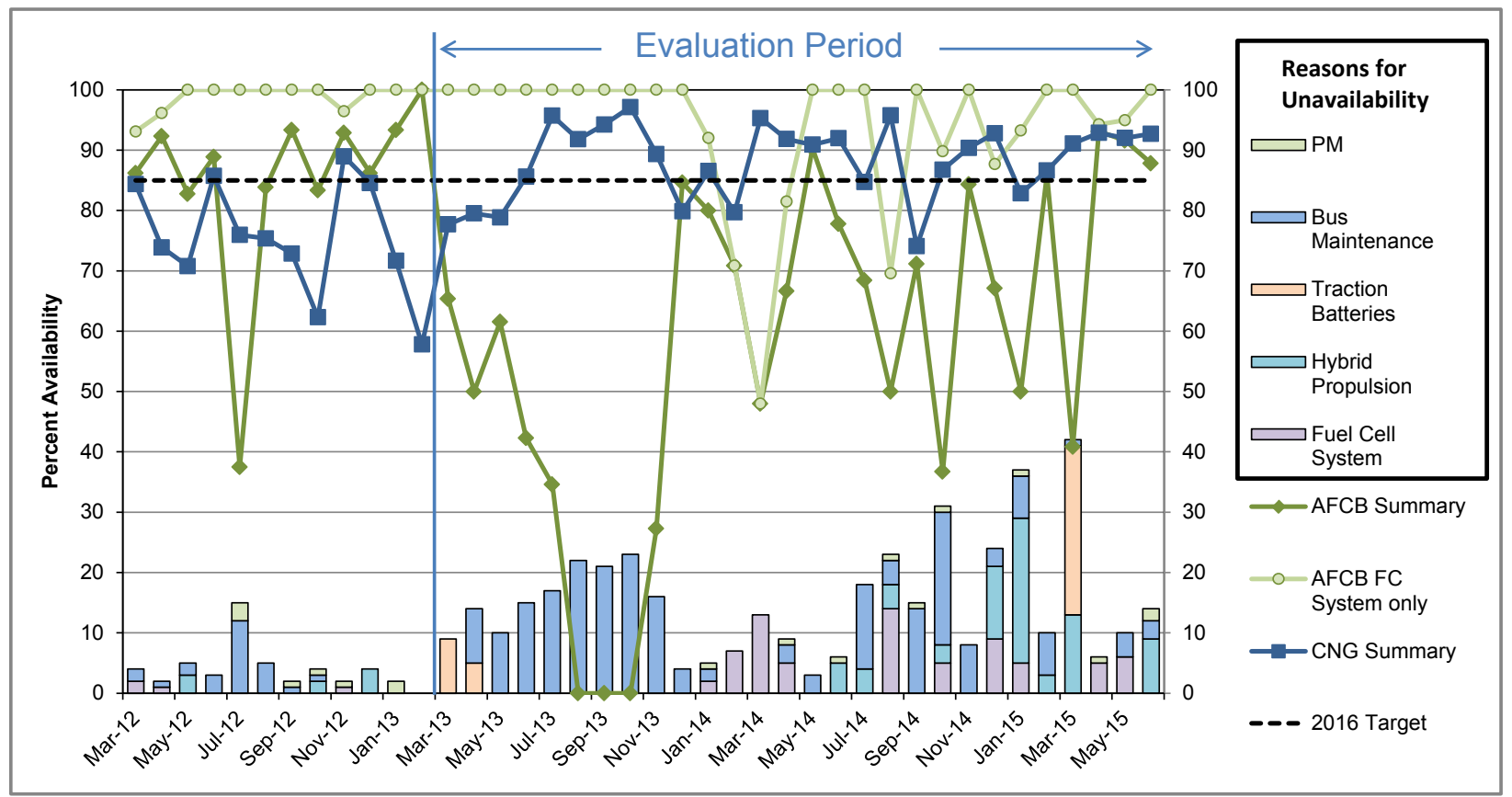

Figure 14. Monthly availability for the AFCBs and CNG buses

During the evaluation period, the average availability for the AFCBs was $66 \%$, with the lowest availability occurring from August through November 2013 due to the radiator issue with FC3. Availability also dropped below 50\% for several additional months during the evaluation period. The overall availability for the fuel cell system was $94 \%$. The availability for the CNG buses was generally higher than the target of $85 \%$.

Table 4 provides a summary of the reasons for availability and unavailability for each of the study bus groups. Overall, during the evaluation period the average availability for the AFCBs was $66 \%$ and the average availability for the CNG buses was $88 \%$. As discussed, the primary issues that kept the AFCBs out of service were downtime for general bus issues $(54 \%)$, the hybrid propulsion (18\%), and the fuel cell system (16\%). For the CNG baseline buses, $49 \%$ of the downtime was attributed to engine issues. Bus 603 had the most days out of service, accounting for $50 \%$ of the total downtime; bus 608 accounted for $25 \%$ of the downtime. 
Table 4. Summary of Reasons for Availability and Unavailability of Buses for Service (Evaluation Period)

\begin{tabular}{|l|c|c|c|c|}
\hline \multirow{2}{*}{\multicolumn{1}{c|}{ Category }} & \multicolumn{2}{c|}{ AFCBs } & \multicolumn{2}{c|}{ CNG Buses } \\
\cline { 2 - 5 } & Number & Percent & Number & Percent \\
\hline Planned work days & 1,270 & & 3,838 & \\
\hline Days available & 838 & 66 & 3,392 & 88 \\
\hline Available & 838 & & 3,392 & \\
\hline On route & 763 & 91 & 3,347 & 99 \\
\hline Event/demonstration & 28 & 3 & 4 & 0 \\
\hline Training & 1 & 0 & 1 & 0 \\
\hline Not used & 45 & 5 & 40 & 1 \\
\hline Unavailable & 432 & & 446 & \\
\hline Fuel cell propulsion & 71 & 16 & - & - \\
\hline CNG engine & - & - & 218 & 49 \\
\hline Hybrid propulsion & 77 & 18 & - & - \\
\hline Traction batteries & 42 & 10 & - & - \\
\hline Preventive maintenance & 10 & 2 & 116 & 26 \\
\hline General bus maintenance & 232 & 54 & 112 & 25 \\
\hline
\end{tabular}

\section{Fuel Economy and Cost}

Table 5 shows hydrogen and CNG fuel economy for the study bus groups during the evaluation period. Using the GGE fuel economy of the CNG buses as a baseline, the AFCBs had a fuel economy 2 times higher than that of the CNG buses. Figure 15 shows the average monthly fuel economy for each of the AFCBs and for the CNG buses as a group.

Table 5. Fuel Use and Economy (Evaluation Period)

\begin{tabular}{|c|c|c|c|c|c|}
\hline Bus & $\begin{array}{c}\text { Mileage } \\
\text { (Fuel Base) }\end{array}$ & $\begin{array}{c}\text { Hydrogen (kg) } \\
\text { or CNG (GGE) }\end{array}$ & $\begin{array}{c}\text { Miles per } \\
\text { kg or } \\
\text { Miles per } \\
\text { GGE }\end{array}$ & $\begin{array}{c}\text { Diesel Equivalent } \\
\text { Amount (Gallon) }\end{array}$ & $\begin{array}{c}\text { Miles per } \\
\text { Gallon (DGE) }\end{array}$ \\
\hline FC3 & 52,790 & $8,312.0$ & 6.35 & $7,355.8$ & 7.18 \\
\hline FC4 & 28,215 & $4,747.1$ & 5.94 & $4,201.0$ & 6.72 \\
\hline FC5 & 16,570 & $3,198.2$ & 5.18 & $2,830.2$ & 5.85 \\
\hline FC6 & 6,507 & $1,255.0$ & 5.18 & $1,110.7$ & 5.86 \\
\hline Total AFCB & $\mathbf{1 0 4 , 0 8 2}$ & $\mathbf{1 7 , 5 1 2 . 3}$ & $\mathbf{5 . 9 4}$ & $\mathbf{1 5 , 4 9 7 . 7}$ & $\mathbf{6 . 7 2}$ \\
\hline 603 CNG & 127,612 & $45,254.3$ & 2.82 & $40,502.6$ & 3.15 \\
\hline 604 CNG & 135,846 & $47,193.6$ & 2.88 & $42,238.3$ & 3.22 \\
\hline 605 CNG & 125,067 & $42,678.2$ & 2.93 & $38,197.0$ & 3.27 \\
\hline 606 CNG & 124,756 & $42,730.2$ & 2.92 & $38,243.6$ & 3.26 \\
\hline 608 CNG & 130,424 & $45,045.4$ & 2.90 & $40,315.6$ & 3.24 \\
\hline Total CNG & $\mathbf{6 4 3 , 7 0 5}$ & $\mathbf{2 2 2 , 9 0 1 . 7}$ & $\mathbf{2 . 8 9}$ & $\mathbf{1 9 9 , 4 9 7 . 1}$ & $\mathbf{3 . 2 3}$ \\
\hline
\end{tabular}




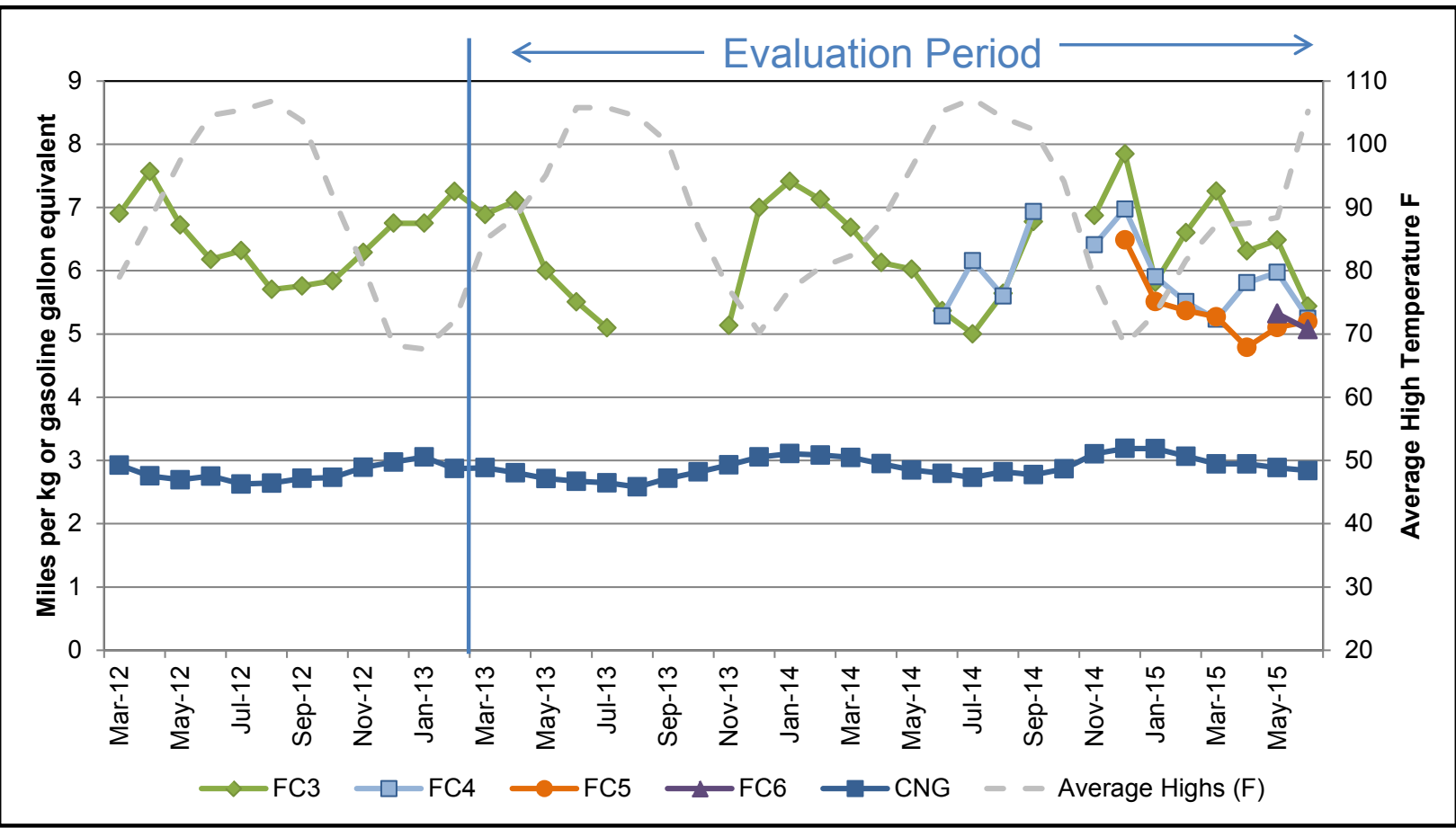

Figure 15. Monthly fuel economy for the AFCBs and CNG buses

The fuel costs per mile for the study bus groups for the evaluation period were $\$ 1.35$ per mile for the AFCBs and \$0.34 per mile for the CNG buses. The CNG fuel cost at \$0.99 per GGE is much lower than the typical average cost per gallon for diesel fuel. The cost to produce hydrogen is much higher and includes the cost of the CNG used for reforming.

\section{Roadcall Analysis}

A roadcall, or revenue vehicle system failure, ${ }^{9}$ is defined as a failure of an in-service bus that causes the bus to be replaced on route or causes a significant delay in schedule. If the problem with the bus can be repaired during a layover and the bus remains on schedule, this is not considered a roadcall. The analysis provided here includes only roadcalls caused by "chargeable" failures. Chargeable roadcalls include systems that can physically disable the bus from operating on route, such as interlocks (doors, air system), engine, or things that are deemed to be safety issues if operation of the bus continues. They do not include roadcalls for things such as problems with radios, fareboxes, or destination signs.

The transit industry measures reliability as mean distance between failures, also documented as miles between roadcalls (MBRC). Figure 16 shows the cumulative monthly MBRC for the AFCBs and CNG buses from March 2012 through June 2015. The DOE/FTA 2016 targets for bus MBRC and fuel cell system MBRC are also included on the graph.

Table 6 provides the MBRC for the AFCBs and CNG buses categorized by bus roadcalls and propulsion-related-only roadcalls. Propulsion-related-only roadcalls include all roadcalls due to propulsion-related systems including the fuel cell system (or engine for a conventional bus), electric drive, fuel, exhaust, air intake, cooling, non-lighting electrical, and transmission systems.

\footnotetext{
${ }^{9}$ Federal Transit Administration's National Transit Database website: www.ntdprogram.gov/ntdprogram/.
} 
The fuel-cell-related roadcalls and MBRC are included for the AFCBs. The fuel cell system MBRC includes any roadcalls due to issues with the fuel cell stack or associated balance of plant. A total of 17 roadcalls for the AFCBs were attributed to the propulsion system. Of these, five were fuel cell related, resulting in a fuel cell system MBRC of 21,789 for the evaluation period. Figure 16 shows the cumulative monthly MBRC for the AFCBs and CNG buses from March 2012 through June 2015. The DOE/FTA 2016 targets for bus MBRC and fuel cell system MBRC are also included on the graph.

Table 6. Roadcalls and MBRC (Evaluation Period)

\begin{tabular}{|l|c|c|c|c|}
\hline & $\begin{array}{c}\text { AFCB } \\
\text { Total }\end{array}$ & $\begin{array}{c}\text { AFCB } \\
\text { Evaluation } \\
\text { Period }\end{array}$ & $\begin{array}{c}\text { CNG } \\
\text { Total }\end{array}$ & $\begin{array}{c}\text { CNG } \\
\text { Evaluation } \\
\text { Period }\end{array}$ \\
\hline Data period & $3 / 12-6 / 15$ & $3 / 13-6 / 15$ & $3 / 12-6 / 15$ & $3 / 13-6 / 15$ \\
\hline Total miles & 151,935 & 108,947 & 898,670 & 670,440 \\
\hline Bus roadcalls & 39 & 28 & 105 & 77 \\
\hline Bus MBRC & 3,896 & 3,891 & 8,559 & 8,707 \\
\hline Propulsion roadcalls & 23 & 17 & 35 & 28 \\
\hline Propulsion MBRC & 6,606 & 6,409 & 25,676 & 23,944 \\
\hline Fuel cell roadcalls & 8 & 5 & - & - \\
\hline Fuel cell MBRC & 18,992 & 21,789 & - & - \\
\hline
\end{tabular}

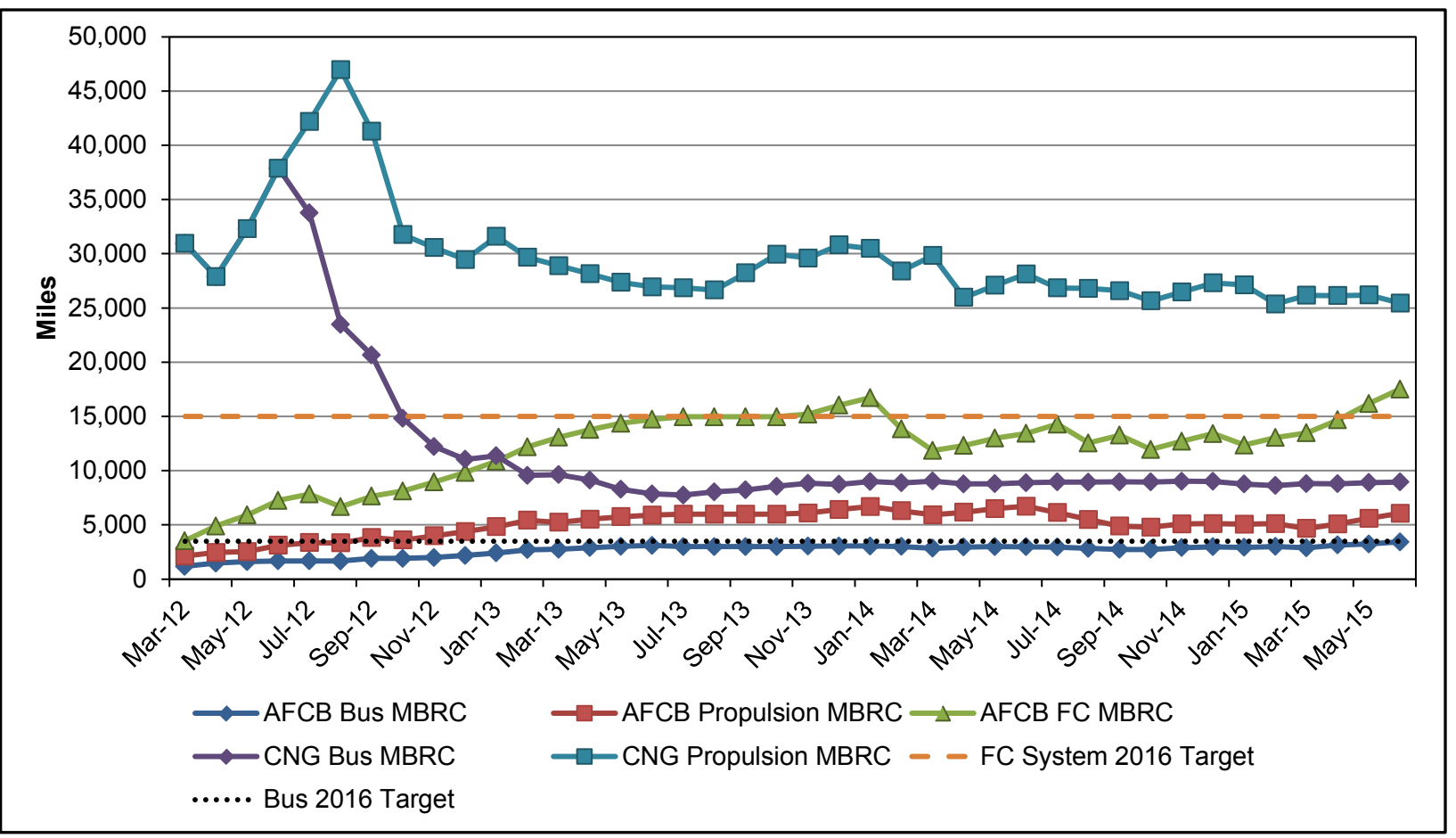

Figure 16. Cumulative monthly MBRC for the AFCBs and CNG buses 


\section{Maintenance Analysis}

The maintenance cost analysis in this section is only for the evaluation period. Warranty costs are generally not included in the cost-per-mile calculations. All work orders for the study buses were collected and analyzed for this evaluation. For consistency with other evaluations, NREL set the maintenance labor rate at $\$ 50$ per hour, which does not reflect an average rate for SunLine. Costs for accident-related repair, which are extremely variable from bus to bus, were eliminated from the analysis. SunLine's CNG buses were manufactured in 2008 and are out of the warranty period. Each of these buses has accumulated more than 350,000 miles and has reached the mid-life point where costs tend to increase. This is evident by the increased costs for engine and other propulsion system maintenance. This section covers total maintenance costs first and then maintenance costs separated by bus system.

\section{Total Maintenance Costs}

Total maintenance costs include the price of parts and hourly labor rates of $\$ 50$ per hour. Cost per mile is calculated as follows:

$$
\text { Cost per mile }=[(\text { labor hours } * 50)+\text { parts cost }] / \text { mileage }
$$

Table 7 shows total maintenance costs for the AFCBs and CNG buses. Scheduled and unscheduled maintenance cost per mile is provided by bus and by group of buses. The AFCBs have total maintenance costs the same as those of the CNG buses. The parts costs continue to be low for the AFCBs because parts for the propulsion system are typically covered by the manufacturer under warranty; however, SunLine's mechanics do nearly all of the work.

Table 7. Total Maintenance Costs (Evaluation Period)

\begin{tabular}{|c|c|c|c|c|c|c|}
\hline Bus & Mileage & Parts (\$) & $\begin{array}{c}\text { Labor } \\
\text { Hours }\end{array}$ & $\begin{array}{c}\text { Total Cost } \\
\text { per Mile } \\
(\$)\end{array}$ & $\begin{array}{c}\text { Scheduled } \\
\text { Cost per Mile } \\
(\$)\end{array}$ & $\begin{array}{c}\text { Unscheduled } \\
\text { Cost per Mile } \\
(\$)\end{array}$ \\
\hline FC3 & 53,555 & 5,857 & 666.3 & 0.73 & 0.07 & 0.66 \\
\hline FC4 & 32,214 & 1,095 & 222.5 & 0.38 & 0.06 & 0.31 \\
\hline FC5 & 16,671 & 985 & 92.0 & 0.34 & 0.04 & 0.29 \\
\hline FC6 & 6,507 & 380 & 39.0 & 0.36 & 0.00 & 0.36 \\
\hline Total AFCB & $\mathbf{1 0 8 , 9 4 7}$ & $\mathbf{8 , 3 1 7}$ & $\mathbf{1 , 0 1 9 . 8}$ & $\mathbf{0 . 5 4}$ & $\mathbf{0 . 0 6}$ & $\mathbf{0 . 4 8}$ \\
\hline 603 CNG & 132,526 & 35,427 & 834.0 & 0.58 & 0.10 & 0.48 \\
\hline 604 CNG & 140,444 & 38,937 & 837.0 & 0.58 & 0.09 & 0.49 \\
\hline 605 CNG & 131,314 & 41,082 & 784.0 & 0.61 & 0.08 & 0.53 \\
\hline 606 CNG & 131,587 & 29,660 & 673.5 & 0.48 & 0.10 & 0.38 \\
\hline 608 CNG & 134,569 & 27,875 & 680.5 & 0.46 & 0.09 & 0.37 \\
\hline Total CNG & $\mathbf{6 7 0 , 4 4 0}$ & $\mathbf{1 7 2 , 9 8 1}$ & $\mathbf{3 , 8 0 9 . 0}$ & $\mathbf{0 . 5 4}$ & $\mathbf{0 . 0 9}$ & $\mathbf{0 . 4 5}$ \\
\hline
\end{tabular}

The monthly scheduled and unscheduled maintenance cost per mile for the AFCBs is shown in Figure 17. Figure 18 provides the same information for the CNG buses. The figures are set to the same scale to enable comparison between the two groups. The high cost per mile for the AFCBs in November 2013 was for labor associated with troubleshooting the bus cooling system issue mentioned earlier. 


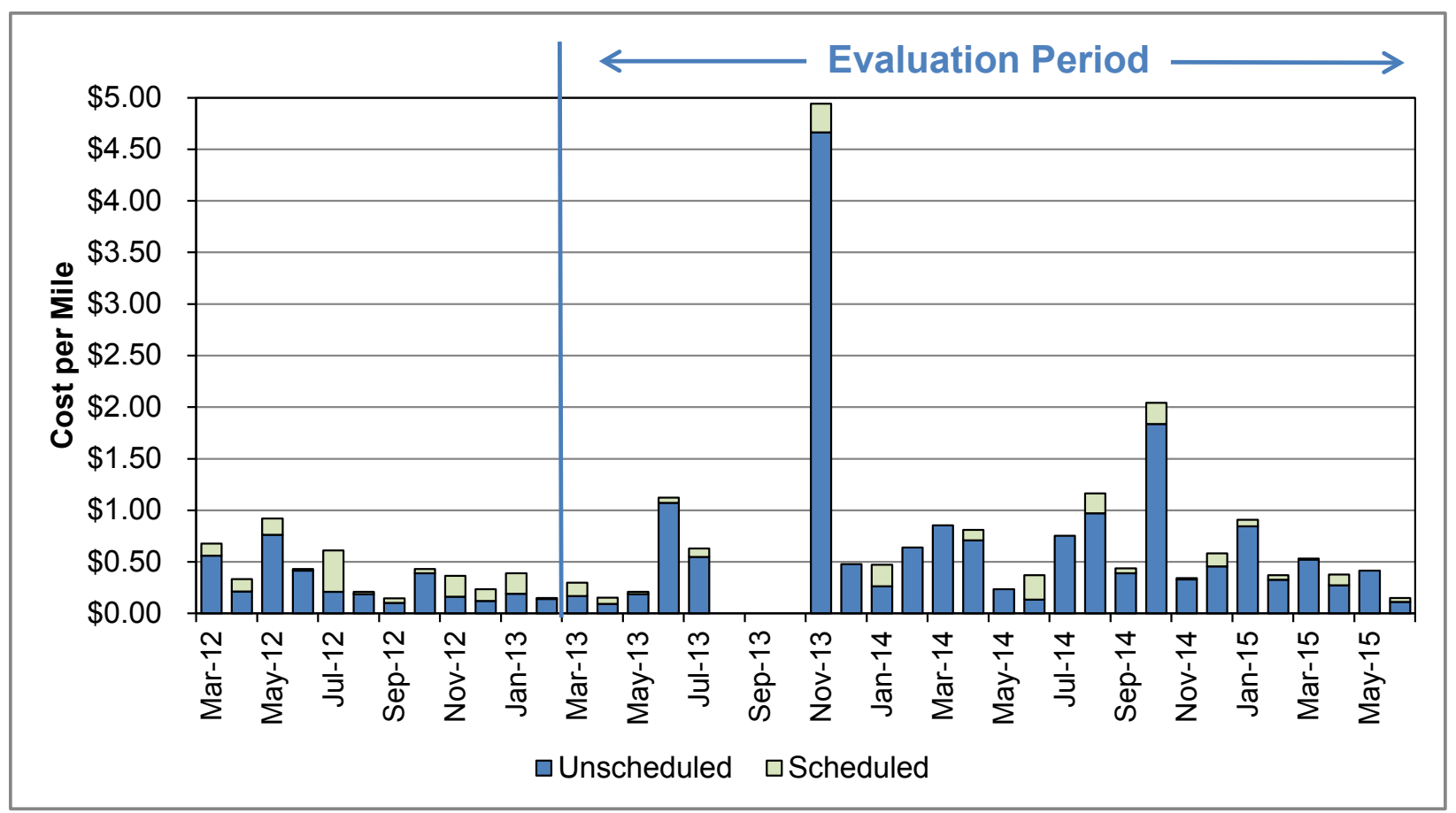

Figure 17. Monthly scheduled and unscheduled maintenance costs per mile for the AFCBs

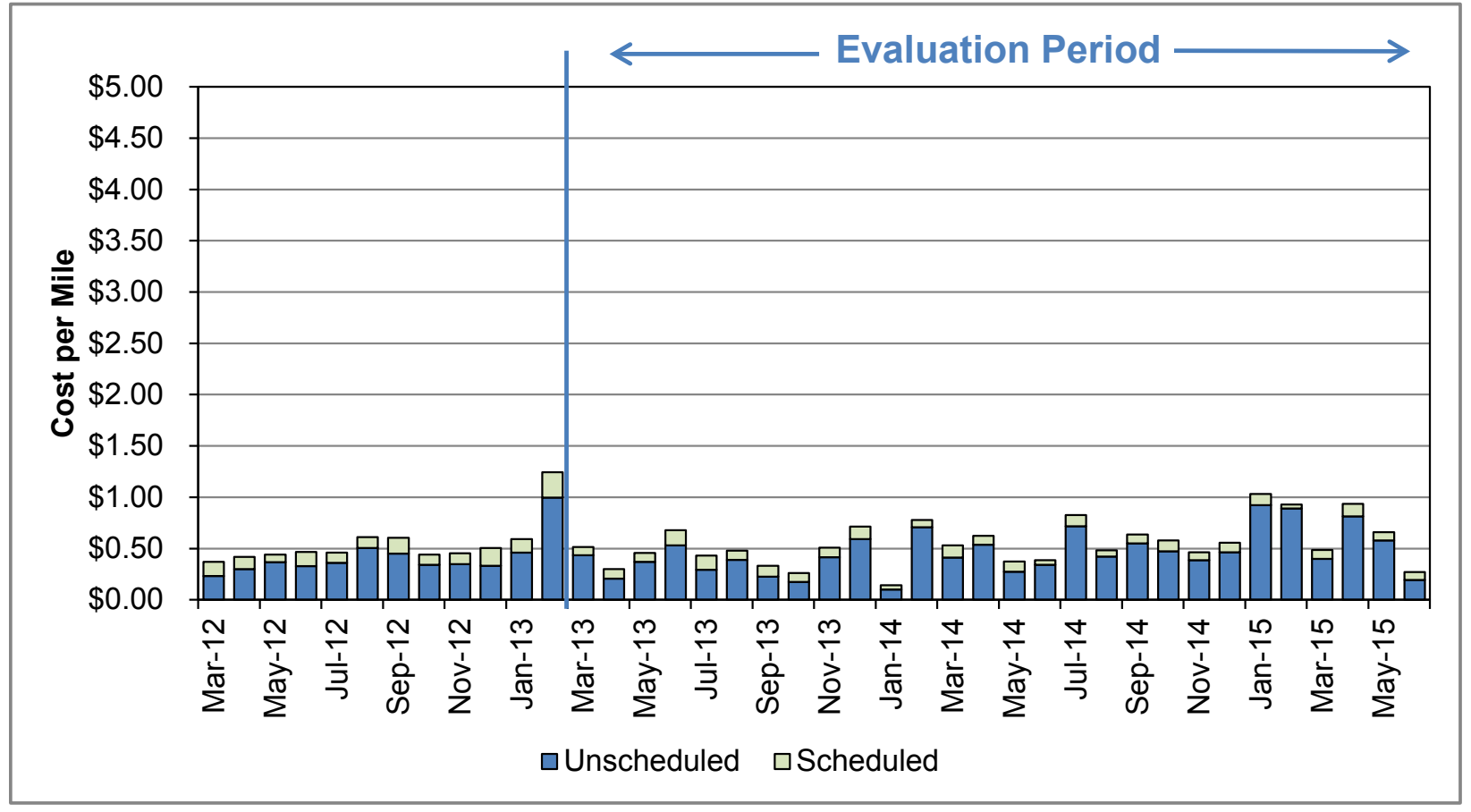

Figure 18. Monthly scheduled and unscheduled maintenance costs per mile for the CNG buses

\section{Maintenance Costs Categorized by System}

Table 8 shows maintenance costs by vehicle system and bus study group (without warranty costs). The vehicle systems shown in the table include the following: 
- Cab, body, and accessories - Includes body, glass, and paint repairs following accidents; cab and sheet metal repairs on seats and doors; and accessory repairs such as hubodometers and radios

- Propulsion-related systems-Repairs for exhaust, fuel, engine, electric motors, fuel cell modules, propulsion control, non-lighting electrical (charging, cranking, and ignition), air intake, cooling, and transmission

- Preventive maintenance inspections (PMI) — Labor for inspections during preventive maintenance

- Brakes

- Frame, steering, and suspension

- Heating, ventilation, and air conditioning (HVAC)

- Lighting

- Air system, general

- Axles, wheels, and drive shaft

- Tires.

Table 8. Vehicle System Maintenance Cost per Mile by System (Evaluation Period)

\begin{tabular}{|l|c|c|c|c|}
\hline \multicolumn{1}{|c|}{ System } & $\begin{array}{c}\text { AFCB } \\
\text { Cost per } \\
\text { Mile (\$) }\end{array}$ & $\begin{array}{c}\text { AFCB } \\
\text { Percent of } \\
\text { Total (\%) }\end{array}$ & $\begin{array}{c}\text { CNG } \\
\text { Cost per } \\
\text { Mile (\$) }\end{array}$ & $\begin{array}{c}\text { CNG } \\
\text { Percent of } \\
\text { Total (\%) }\end{array}$ \\
\hline Propulsion-related & 0.34 & 63 & 0.24 & 43 \\
\hline Cab, body, and accessories & 0.07 & 13 & 0.09 & 16 \\
\hline PMI & 0.06 & 11 & 0.06 & 11 \\
\hline Brakes & 0.01 & 2 & 0.03 & 6 \\
\hline Frame, steering, and suspension & 0.03 & 6 & 0.01 & 2 \\
\hline HVAC & 0.00 & 1 & 0.07 & 12 \\
\hline Lighting & 0.01 & 2 & 0.01 & 2 \\
\hline General air system repairs & 0.00 & 0 & 0.01 & 2 \\
\hline Axles, wheels, and drive shaft & 0.01 & 1 & 0.02 & 3 \\
\hline Tires & 0.01 & 1 & 0.01 & 1 \\
\hline Total & $\mathbf{0 . 5 4}$ & 100 & $\mathbf{0 . 5 4}$ & 100 \\
\hline
\end{tabular}

For the AFCBs, the systems with the highest percentage of maintenance costs were propulsionrelated; cab, body, and accessories; and PMI. The same categories made up the highest percentage of maintenance costs for the CNG buses. The CNG buses continue to experience engine issues typical of buses at the mid-point of expected life. Figure 19 shows the monthly maintenance cost per mile by category for the AFCBs and Figure 20 provides the monthly maintenance cost by category for the CNG buses. 


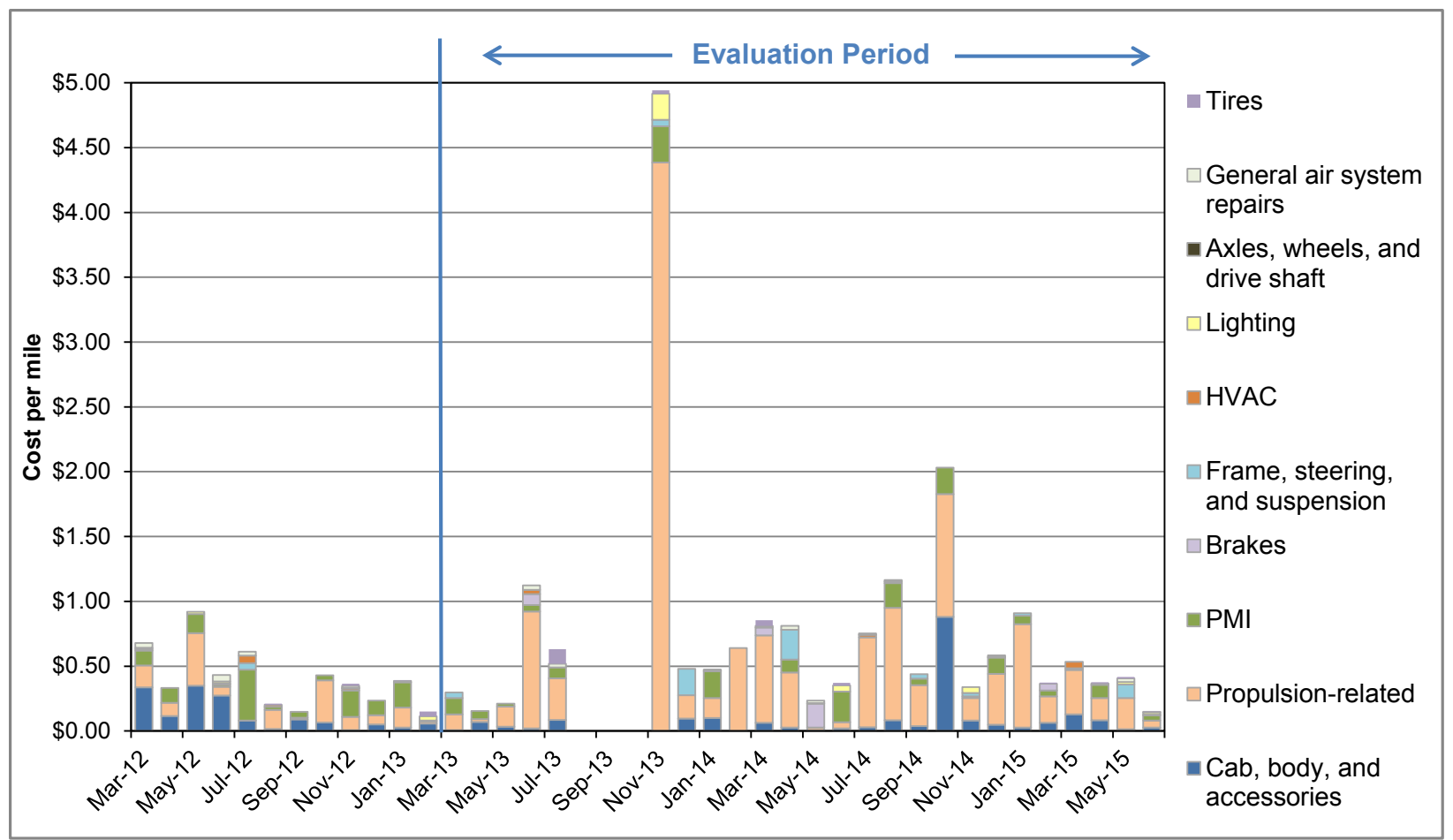

Figure 19. Monthly maintenance cost per mile by category for the AFCBs

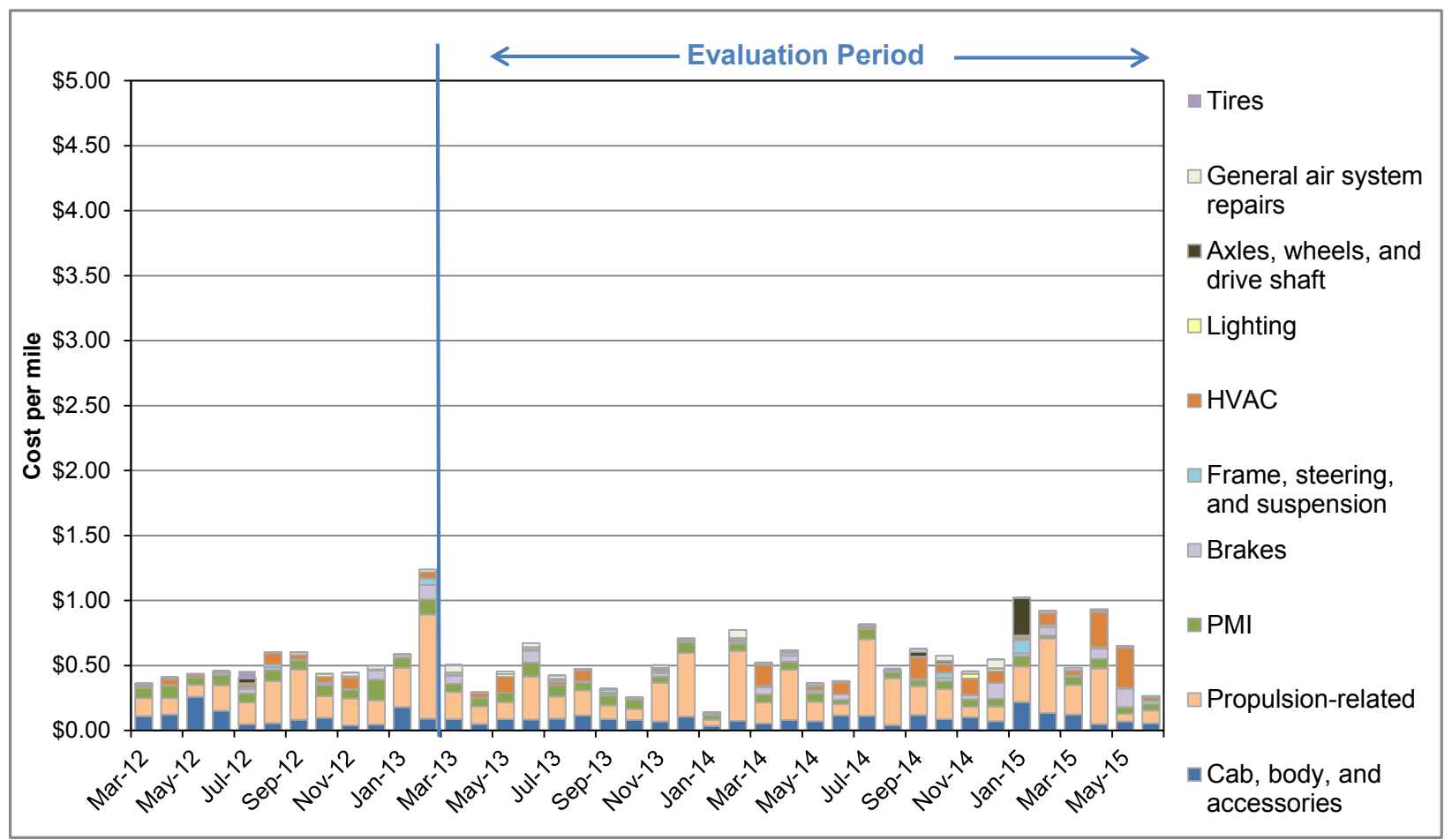

Figure 20. Monthly maintenance cost per mile by category for the CNG buses 


\section{Propulsion-Related Maintenance Costs}

The propulsion-related vehicle systems include the exhaust, fuel, engine, electric propulsion, air intake, cooling, non-lighting electrical, and transmission systems. Table 9 categorizes the propulsion-related system repairs for the study bus groups during the evaluation period (not including warranty). The AFCBs were under warranty for most of the key systems during the entire evaluation period. The CNG buses are no longer under warranty. The SunLine mechanics continue to handle nearly all of the maintenance on the AFCBs, with support as needed by the manufacturers. However, the manufacturers generally supplied the parts under warranty for the propulsion system, so the costs for these parts are not included in the maintenance costs.

- Total propulsion-related-The propulsion-related maintenance cost was $44 \%$ higher for the AFCBs compared with the CNG buses. The majority of this maintenance for the AFCBs has been labor.

- Exhaust system—Costs for this system for the study bus groups were low or zero.

- Fuel system-The cost for this system for the AFCBs was higher than previously reported due to a tank valve issue. Costs for this system for the CNG bus group were low.

- Power plant and electric propulsion-The power-plant-related maintenance cost for the AFCBs was only $2 \%$ lower than the cost of the engine-related work for the CNG buses. The AFCB maintenance reported here was almost exclusively labor for SunLine mechanics - for troubleshooting and making the repairs on the bus or supporting manufacturer work on the bus. There are no electric propulsion costs for the CNG buses because they are not hybrids. The engine issues for the CNG buses caused a significant increase in the power plant category.

- Non-lighting electrical (charging, cranking, and ignition)-The AFCB costs in this category were primarily for replacing bus batteries. The CNG buses mostly had preventive maintenance repairs in this category, for spark plugs at the 24,000-mile preventive-maintenance cycle for each bus. Three buses also had alternators replaced.

- Air intake - Costs for this system for the study bus groups were low.

- Cooling - The AFCBs had high costs for troubleshooting and repair of the radiator leak for FC3. Costs for this system for the CNG bus group were low.

- Transmission-Costs for this system for the CNG buses were low. The AFCBs do not have a traditional transmission; costs are included in the electric propulsion category. 
Table 9. Propulsion-Related Maintenance Costs by System (Evaluation Period)

\begin{tabular}{|c|c|c|c|}
\hline Maintenance System & Maintenance Costs & $\mathrm{AFCB}$ & CNG \\
\hline Mileage & & 108,947 & 670,440 \\
\hline \multirow{4}{*}{$\begin{array}{l}\text { Total Propulsion- } \\
\text { Related Systems } \\
\text { (Roll-up) }\end{array}$} & Parts cost $(\$)$ & 3,198 & 91,647 \\
\hline & Labor hours & 677.3 & $1,326.3$ \\
\hline & Total cost $(\$)$ & 37,061 & 157,960 \\
\hline & Total cost (\$) per mile & 0.34 & 0.24 \\
\hline \multirow{4}{*}{$\begin{array}{l}\text { Exhaust System } \\
\text { Repairs }\end{array}$} & Parts cost $(\$)$ & 0 & 5,883 \\
\hline & Labor hours & 0.0 & 31.5 \\
\hline & Total cost $(\$)$ & 0 & 7,458 \\
\hline & Total cost (\$) per mile & 0.00 & 0.01 \\
\hline \multirow{4}{*}{ Fuel System Repairs } & Parts cost $(\$)$ & 0 & 3,880 \\
\hline & Labor hours & 59.3 & 7.5 \\
\hline & Total cost $(\$)$ & 2,963 & 4,255 \\
\hline & Total cost $(\$)$ per mile & 0.03 & 0.01 \\
\hline \multirow{4}{*}{$\begin{array}{l}\text { Power Plant System } \\
\text { Repairs }\end{array}$} & Parts cost $(\$)$ & 96 & 49,451 \\
\hline & Labor hours & 240.0 & $1,029.8$ \\
\hline & Total cost $(\$)$ & 12,096 & 100,938 \\
\hline & Total cost (\$) per mile & 0.11 & 0.15 \\
\hline \multirow{4}{*}{$\begin{array}{l}\text { Electric Propulsion } \\
\text { System Repairs }\end{array}$} & Parts cost $(\$)$ & 5 & 0 \\
\hline & Labor hours & 80.5 & 0.0 \\
\hline & Total cost $(\$)$ & 4,030 & 0 \\
\hline & Total cost (\$) per mile & 0.04 & 0.00 \\
\hline \multirow{4}{*}{$\begin{array}{l}\text { Non-Lighting Electrical } \\
\text { System Repairs } \\
\text { (General Electrical, } \\
\text { Charging, Cranking, } \\
\text { Ignition) }\end{array}$} & Parts cost $(\$)$ & 3,068 & 22,007 \\
\hline & Labor hours & 76.3 & 79.5 \\
\hline & Total cost $(\$)$ & 6,881 & 25,982 \\
\hline & Total cost $(\$)$ per mile & 0.06 & 0.04 \\
\hline \multirow{4}{*}{$\begin{array}{l}\text { Air Intake System } \\
\text { Repairs }\end{array}$} & Parts cost $(\$)$ & 9 & 2,492 \\
\hline & Labor hours & 0.0 & 1.0 \\
\hline & Total cost $(\$)$ & 9 & 2,542 \\
\hline & Total cost (\$) per mile & 0.00 & 0.00 \\
\hline \multirow{4}{*}{$\begin{array}{l}\text { Cooling System } \\
\text { Repairs }\end{array}$} & Parts cost $(\$)$ & 21 & 3,760 \\
\hline & Labor hours & 221.3 & 143.0 \\
\hline & Total cost $(\$)$ & 11,083 & 10,910 \\
\hline & Total cost (\$) per mile & 0.10 & 0.02 \\
\hline \multirow{4}{*}{$\begin{array}{l}\text { Transmission System } \\
\text { Repairs }\end{array}$} & Parts cost $(\$)$ & 0 & 1,546 \\
\hline & Labor hours & 0.0 & 27.0 \\
\hline & Total cost $(\$)$ & 0 & 2,896 \\
\hline & Total cost (\$) per mile & 0.00 & 0.00 \\
\hline \multirow{4}{*}{$\begin{array}{l}\text { Hydraulic System } \\
\text { Repairs }\end{array}$} & Parts cost $(\$)$ & 0 & 2,629 \\
\hline & Labor hours & 0.0 & 7.0 \\
\hline & Total cost $(\$)$ & 0 & 2,979 \\
\hline & Total cost $(\$)$ per mile & 0.00 & 0.00 \\
\hline
\end{tabular}




\section{What's Next for SunLine}

This report covers SunLine's operation of the AFCBs and CNG buses through June 2015. The agency will continue working with NREL to collect data on the buses in service. SunLine has received funding for several new projects that will add FCEBs to its fleet. Table 10 summarizes the current and upcoming FCEB bus projects for SunLine.

Table 10. Summary of Current and Planned FCEB Projects at SunLine

\begin{tabular}{|l|c|c|l|l|}
\hline \multicolumn{1}{|c|}{ Project } & Funding Program & $\begin{array}{c}\# \\
\text { Buses }\end{array}$ & \multicolumn{1}{|c|}{ Description } & In Service \\
Start
\end{tabular}




\section{Contacts}

DOE

1000 Independence Ave., SW

Washington, DC 20585

Jason Marcinkoski, Technology Development Manager, Fuel Cell Technologies Office

Phone: 202-586-7466

Email: jason.marcinkoski@ee.doe.gov

\section{NREL}

15013 Denver West Parkway

Golden, CO 80401

Leslie Eudy, Senior Project Leader

Phone: 303-275-4412

Email: leslie.eudy@nrel.gov

\section{SunLine}

32-505 Harry Oliver Trail

Thousand Palms, CA 92276

Tommy Edwards, Contracting Officer Technical Representative

Phone: 760-343-3456

Email: tedwards@sunline.org

\section{BAE Systems}

1098 Clark St / Huron Campus

Endicott, NY 13760

Yeshwanth Premkumar, Program Manager - Fuel Cell Bus \& Maritime Programs

Phone: 607-240-9316

Email: Yeshwanth.Premkumar@baesystems.com

\section{Ballard Power Systems}

9000 Glenyon Parkway

Burnaby, BC, Canada

Jeff Grant, Business Development Manager

Phone: 604-453-3578

Email: jeff.grant@,ballard.com 
EIDorado National

9670 Galena St.

Riverside, CA 92509

Khalil Subat, Chief Engineer

Phone: 909-591-9557

Email: ksubat@eldorado-ca.com

\section{CALSTART}

48 S. Chester Avenue

Pasadena, CA 91106

Lawrence Wnuk, Senior Director

Phone: 626-744-5685

Email:1wnuk@,calstart.org 


\section{References and Related Reports}

All NREL hydrogen and fuel cell-related evaluation reports can be downloaded from the following website: www.nrel.gov/hydrogen/proj_fc bus_eval.html.

\section{Other SunLine Reports}

Eudy, L.; Chandler, K. (2013). American Fuel Cell Bus Project: First Analysis Report. FTA Report No. 0047. Washington, DC: Federal Transit Administration.

Eudy, L.; Chandler, K. (2013). SunLine Transit Agency Advanced Technology Fuel Cell Bus Evaluation: Fourth Results Report. NREL/TP-5600-57560. Golden, CO: National Renewable Energy Laboratory.

\section{General}

Eudy, L.; Post, M.; Gikakis, C. (2014). Fuel Cell Buses in U.S. Transit Fleets: Current Status 2014. NREL/TP-5400-62683. Golden, CO: National Renewable Energy Laboratory.

Chandler, K.; Eudy, L. (2012). FTA Fuel Cell Bus Program: Research Accomplishments through 2011. FTA Report No. 0014. Washington, DC: Federal Transit Administration.

Eudy, L. (2010). Fuel Cell Transit Bus Evaluations, Joint Evaluation Plan for the U.S. Department of Energy and the Federal Transit Administration. NREL/TP-560-49342. Golden, CO: National Renewable Energy Laboratory. 


\section{Appendix A: TRL Guideline Table}

\section{Technology Readiness Levels for FCEB Commercialization}

\begin{tabular}{|c|c|c|c|}
\hline $\begin{array}{l}\text { Relative Level of } \\
\text { Technology } \\
\text { Development } \\
\end{array}$ & $\begin{array}{l}\text { Technology } \\
\text { Readiness } \\
\text { Level } \\
\end{array}$ & TRL Definition & Description \\
\hline Deployment & TRL 9 & $\begin{array}{l}\text { Actual system } \\
\text { operated over the full } \\
\text { range of expected } \\
\text { conditions }\end{array}$ & $\begin{array}{l}\text { The technology is in its final form. } \\
\text { Deployment, marketing, and support begin } \\
\text { for the first fully commercial products. }\end{array}$ \\
\hline \multirow{3}{*}{$\begin{array}{l}\text { Technology } \\
\text { Demonstration/ } \\
\text { Commissioning }\end{array}$} & TRL 8 & $\begin{array}{l}\text { Actual system } \\
\text { completed and } \\
\text { qualified through test } \\
\text { and demonstration }\end{array}$ & $\begin{array}{l}\text { The last step in true system development. } \\
\text { Demonstration of a limited production of } 50 \\
\text { to } 100 \text { buses at a small number of } \\
\text { locations. Beginning the transition of all } \\
\text { maintenance to transit staff. }\end{array}$ \\
\hline & TRL 7 & $\begin{array}{l}\text { Full-scale validation in } \\
\text { relevant environment }\end{array}$ & $\begin{array}{l}\text { A major step up from TRL } 6 \text { by adding } \\
\text { larger numbers of buses and increasing the } \\
\text { hours of service. Full-scale demonstration } \\
\text { and reliability testing of } 5 \text { to } 10 \text { buses at } \\
\text { several locations. Manufacturers begin to } \\
\text { train larger numbers of transit staff in } \\
\text { operation and maintenance. }\end{array}$ \\
\hline & TRL 6 & $\begin{array}{l}\text { Engineering/pilot-scale } \\
\text { validation in relevant } \\
\text { environment }\end{array}$ & $\begin{array}{l}\text { First tests of prototype buses in actual } \\
\text { transit service. Field testing and design } \\
\text { shakedown of } 1 \text { to } 2 \text { prototypes. } \\
\text { Manufacturers assist in operation and } \\
\text { typically handle all maintenance. Begin to } \\
\text { introduce transit staff to technology. }\end{array}$ \\
\hline \multirow{2}{*}{$\begin{array}{l}\text { Technology } \\
\text { Development }\end{array}$} & TRL 5 & $\begin{array}{l}\text { Laboratory scale, } \\
\text { similar system } \\
\text { validation in relevant } \\
\text { environment }\end{array}$ & $\begin{array}{l}\text { Integrated system is tested in a laboratory } \\
\text { under simulated conditions based on early } \\
\text { modeling. System is integrated into an } \\
\text { early prototype or mule platform for some } \\
\text { on-road testing. }\end{array}$ \\
\hline & TRL 4 & $\begin{array}{l}\text { Component and } \\
\text { system validation in } \\
\text { laboratory environment }\end{array}$ & $\begin{array}{l}\text { Basic technological components are } \\
\text { integrated into the system and begin } \\
\text { laboratory testing and modeling of potential } \\
\text { duty cycles. }\end{array}$ \\
\hline \multirow[t]{2}{*}{$\begin{array}{l}\text { Research to Prove } \\
\text { Feasibility }\end{array}$} & TRL 3 & $\begin{array}{c}\text { Analytical and } \\
\text { experimental critical } \\
\text { function and/or proof of } \\
\text { concept } \\
\end{array}$ & $\begin{array}{l}\text { Active research into components and } \\
\text { system integration needs. Investigate what } \\
\text { requirements might be met with existing } \\
\text { commercial components. }\end{array}$ \\
\hline & TRL 2 & $\begin{array}{l}\text { Technology concept } \\
\text { and/or application } \\
\text { formulated }\end{array}$ & $\begin{array}{l}\text { Research technology needed to meet } \\
\text { market requirements. Define strategy for } \\
\text { moving through development stages. }\end{array}$ \\
\hline $\begin{array}{l}\text { Basic Technology } \\
\text { Research }\end{array}$ & TRL 1 & $\begin{array}{c}\text { Basic principles } \\
\text { observed and reported }\end{array}$ & $\begin{array}{l}\text { Scientific research and early development } \\
\text { of FCEB concepts. }\end{array}$ \\
\hline
\end{tabular}




\section{Appendix B: Fleet Summary Statistics}

\section{Fleet Summary Statistics: SunLine Transit Agency \\ AFCB and CNG Study Groups \\ Fleet Operations and Economics}

\begin{tabular}{|c|c|c|c|c|}
\hline & $\begin{array}{c}\text { AFCB } \\
\text { All Data }\end{array}$ & $\begin{array}{c}\text { AFCB } \\
\text { New Data }\end{array}$ & $\begin{array}{c}\text { CNG } \\
\text { All Data }\end{array}$ & $\begin{array}{c}\text { CNG } \\
\text { New Data }\end{array}$ \\
\hline Number of vehicles & 4 & 4 & 5 & 5 \\
\hline Period used for fuel and oil op analysis & $3 / 12-6 / 15$ & $3 / 13-6 / 15$ & $3 / 12-6 / 15$ & $3 / 13-6 / 15$ \\
\hline Total number of months in period & 40 & 28 & 40 & 28 \\
\hline Fuel and oil analysis base fleet mileage & 147,070 & 104,082 & 895,737 & 667,512 \\
\hline Period used for maintenance op analysis & $3 / 12-6 / 15$ & $3 / 13-6 / 15$ & $3 / 12-6 / 15$ & $3 / 13-6 / 15$ \\
\hline Total number of months in period & 40 & 28 & 40 & 28 \\
\hline Maintenance analysis base fleet mileage & 151,935 & 108,947 & 898,670 & 670,440 \\
\hline Average monthly mileage per vehicle & 2,491 & 2,223 & 4,493 & 4,789 \\
\hline Availability & 70 & 66 & 85 & 88 \\
\hline Fleet fuel usage in $\mathrm{kg} \mathrm{H}_{2}$ or GGE CNG & $24,085.2$ & $17,512.4$ & $312,701.9$ & $231,287.2$ \\
\hline Roadcalls & 39 & 28 & 105 & 77 \\
\hline Total MBRC & 3,896 & 3,891 & 8,559 & 8,707 \\
\hline Propulsion roadcalls & 23 & 17 & 35 & 28 \\
\hline Propulsion MBRC & 6,606 & 6,409 & 25,676 & 23,944 \\
\hline Fleet miles/kg hydrogen (1.13 $\left.\mathrm{kg} \mathrm{H}_{2} / \mathrm{GGE} \mathrm{CNG}\right)$ & 6.11 & 5.94 & 2.86 & 2.89 \\
\hline Representative fleet MPG (energy equiv) & 6.90 & 6.72 & 3.20 & 3.22 \\
\hline \multirow{3}{*}{$\begin{array}{l}\text { Hydrogen cost per kg } \\
\text { CNG cost per GGE } \\
\text { Fuel cost per mile }\end{array}$} & 8.00 & 8.00 & & \\
\hline & & & 0.99 & 0.99 \\
\hline & 1.31 & 1.35 & 0.35 & 0.34 \\
\hline Total scheduled repair cost per mile & 0.07 & 0.06 & 0.10 & 0.09 \\
\hline Total unscheduled repair cost per mile & 0.43 & 0.48 & 0.44 & 0.45 \\
\hline Total maintenance cost per mile & 0.50 & 0.54 & 0.54 & 0.54 \\
\hline Total operating cost per mile & 1.81 & 1.89 & 0.88 & 0.89 \\
\hline
\end{tabular}

\section{Maintenance Costs}

\begin{tabular}{|l|r|r|r|r|}
\hline & \multicolumn{1}{|c|}{ AFCB } & \multicolumn{1}{c|}{ AFCB } \\
& All Data & \multicolumn{1}{c|}{$\begin{array}{c}\text { CNG } \\
\text { New Data }\end{array}$} & \multicolumn{1}{c|}{ CNG } \\
All Data & \multicolumn{1}{c|}{ New Data } \\
\hline Fleet mileage & 151,935 & 108,947 & 898,670 & 670,440 \\
\hline Total parts cost & $9,826.11$ & $8,317.38$ & $213,768.53$ & $172,980.67$ \\
Total labor hours & $1,323.3$ & $1,019.0$ & $5,394.8$ & $3,809.0$ \\
Average labor cost $@ \$ 50.00$ per hour) & $66,162.50$ & $50,950.00$ & $269,737.50$ & $190,450.00$ \\
Total maintenance cost & $75,988.61$ & $59,267.38$ & $483,506.03$ & $363,430.67$ \\
\hline Total maintenance cost per bus & $1,899.72$ & $1,481.68$ & $17,268.07$ & $12,979.67$ \\
\hline Total maintenance cost per mile & $\mathbf{0 . 5 0}$ & $\mathbf{0 . 5 4}$ & $\mathbf{0 . 5 4}$ & $\mathbf{0 . 5 4}$ \\
\hline
\end{tabular}


Maintenance Costs by Vehicle System

\begin{tabular}{|c|c|c|c|c|}
\hline & $\begin{array}{l}\text { AFCB } \\
\text { All Data }\end{array}$ & $\begin{array}{l}\text { AFCB } \\
\text { New Data }\end{array}$ & $\begin{array}{l}\text { CNG } \\
\text { All Data } \\
\end{array}$ & $\begin{array}{l}\text { CNG } \\
\text { New Data }\end{array}$ \\
\hline Fleet mileage & 151,935 & 108,947 & 898,670 & 670,440 \\
\hline \multicolumn{5}{|c|}{ Total Engine/Fuel-Related Systems (ATA VMRS 27, 30, 31, 32, 33, 41, 42, 43, 44, 45, 46, 65) } \\
\hline Parts cost & $3,725.27$ & $3,198.35$ & $115,501.73$ & $91,647.13$ \\
\hline Labor hours & 770.00 & 677.25 & $1,943.75$ & $1,326.25$ \\
\hline Average labor cost & $38,500.00$ & $33,862.50$ & $97,187.50$ & $66,312.50$ \\
\hline Total cost (for system) & $42,225.27$ & $37,060.85$ & $212,689.23$ & $157,959.63$ \\
\hline Total cost (for system) per bus & $1,055.63$ & 926.52 & $7,596.04$ & $5,641.42$ \\
\hline Total cost (for system) per mile & 0.28 & 0.34 & 0.24 & 0.24 \\
\hline \multicolumn{5}{|c|}{ Exhaust System Repairs (ATA VMRS 43) } \\
\hline Parts cost & 0.00 & 0.00 & $7,542.07$ & $5,883.11$ \\
\hline Labor hours & 0.0 & 0.0 & 38.0 & 31.5 \\
\hline Average labor cost & 0.00 & 0.00 & $1,900.00$ & $1,575.00$ \\
\hline Total cost (for system) & 0.00 & 0.00 & $9,442.07$ & $7,458.11$ \\
\hline Total cost (for system) per bus & 0.00 & 0.00 & 337.22 & 266.36 \\
\hline Total cost (for system) per mile & 0.00 & 0.00 & 0.01 & 0.01 \\
\hline \multicolumn{5}{|c|}{ Fuel System Repairs (ATA VMRS 44) } \\
\hline Parts cost & 0.00 & 0.00 & $4,111.65$ & $3,880.18$ \\
\hline Labor hours & 76.3 & 59.3 & 7.5 & 7.5 \\
\hline Average labor cost & $3,812.50$ & $2,962.50$ & 375.00 & 375.00 \\
\hline Total cost (for system) & $3,812.50$ & $2,962.50$ & $4,486.65$ & $4,255.18$ \\
\hline Total cost (for system) per bus & 95.31 & 74.06 & 160.24 & 151.97 \\
\hline Total cost (for system) per mile & 0.03 & 0.03 & 0.00 & 0.01 \\
\hline \multicolumn{5}{|c|}{ Power Plant (Engine) Repairs (ATA VMRS 45) } \\
\hline Parts cost & 104.63 & 95.55 & $62,394.43$ & $49,450.52$ \\
\hline Labor hours & 267.0 & 240.0 & $1,511.3$ & $1,029.8$ \\
\hline Average labor cost & $13,350.00$ & $12,000.00$ & $75,562.50$ & $51,487.50$ \\
\hline Total cost (for system) & $13,454.63$ & $12,095.55$ & $137,956.93$ & $100,938.02$ \\
\hline Total cost (for system) per bus & 336.37 & 302.39 & $4,927.03$ & $3,604.93$ \\
\hline Total cost (for system) per mile & 0.09 & 0.11 & 0.15 & 0.15 \\
\hline \multicolumn{5}{|c|}{ Electric Propulsion Repairs (ATA VMRS 46) } \\
\hline Parts cost & 59.00 & 5.44 & 0.00 & 0.00 \\
\hline Labor hours & 104.8 & 80.5 & 0.0 & 0.0 \\
\hline Average labor cost & $5,237.50$ & $4,025.00$ & 0.00 & 0.00 \\
\hline Total cost (for system) & $5,296.50$ & $4,030.44$ & 0.00 & 0.00 \\
\hline Total cost (for system) per bus & 132.41 & 100.76 & 0.00 & 0.00 \\
\hline Total cost (for system) per mile & 0.03 & 0.04 & 0.00 & 0.00 \\
\hline \multicolumn{5}{|c|}{$\begin{array}{l}\text { Electrical System Repairs (ATA VMRS 30-Electrical General, 31-Charging, 32-Cranking, 33- } \\
\text { Ignition) }\end{array}$} \\
\hline Parts cost & $3,532.41$ & $3,068.13$ & $28,909.81$ & $22,006.92$ \\
\hline Labor hours & 85.5 & 76.3 & 106.3 & 79.5 \\
\hline Average labor cost & $4,275.00$ & $3,812.50$ & $5,312.50$ & $3,975.00$ \\
\hline Total cost (for system) & $7,807.41$ & $6,880.63$ & $34,222.31$ & $25,981.92$ \\
\hline Total cost (for system) per bus & 195.19 & 172.02 & $1,222.23$ & 927.93 \\
\hline Total cost (for system) per mile & 0.05 & 0.06 & 0.04 & 0.04 \\
\hline
\end{tabular}




\begin{tabular}{|c|c|c|c|c|}
\hline & $\begin{array}{c}\text { AFCB } \\
\text { All Data }\end{array}$ & $\begin{array}{c}\text { AFCB } \\
\text { New Data }\end{array}$ & $\begin{array}{c}\text { CNG } \\
\text { All Data }\end{array}$ & $\begin{array}{c}\text { CNG } \\
\text { New Data }\end{array}$ \\
\hline \multicolumn{5}{|c|}{ Air Intake System Repairs (ATA VMRS 41) } \\
\hline Parts cost & 8.58 & 8.58 & $3,223.17$ & $2,492.30$ \\
\hline Labor hours & 0.0 & 0.0 & 1.0 & 1.0 \\
\hline Average labor cost & 0.00 & 0.00 & 50.00 & 50.00 \\
\hline Total cost (for system) & 8.58 & 8.58 & $3,273.17$ & $2,542.30$ \\
\hline Total cost (for system) per bus & 0.21 & 0.21 & 116.90 & 90.80 \\
\hline Total cost (for system) per mile & 0.00 & 0.00 & 0.00 & 0.00 \\
\hline \multicolumn{5}{|c|}{ Cooling System Repairs (ATA VMRS 42) } \\
\hline Parts cost & 20.65 & 20.65 & $4,188.13$ & $3,759.85$ \\
\hline Labor hours & 236.5 & 221.3 & 231.0 & 143.0 \\
\hline Average labor cost & $11,825.00$ & $11,062.50$ & $11,550.00$ & $7,150.00$ \\
\hline Total cost (for system) & $11,845.65$ & $11,083.15$ & $15,738.13$ & $10,909.85$ \\
\hline Total cost (for system) per bus & 296.14 & 277.08 & 562.08 & 389.64 \\
\hline Total cost (for system) per mile & 0.08 & 0.10 & 0.02 & 0.02 \\
\hline \multicolumn{5}{|c|}{ Hydraulic System Repairs (ATA VMRS 65) } \\
\hline Parts cost & 0.00 & 0.00 & $2,942.83$ & $2,628.65$ \\
\hline Labor hours & 0.0 & 0.0 & 7.0 & 7.0 \\
\hline Average labor cost & 0.00 & 0.00 & 350.00 & 350.00 \\
\hline Total cost (for system) & 0.00 & 0.00 & $3,292.83$ & $2,978.65$ \\
\hline Total cost (for system) per bus & 0.00 & 0.00 & 117.60 & 106.38 \\
\hline Total cost (for system) per mile & 0.00 & 0.00 & 0.00 & 0.00 \\
\hline \multicolumn{5}{|c|}{ General Air System Repairs (ATA VMRS 10) } \\
\hline Parts cost & 405.82 & 405.82 & $2,636.35$ & $2,560.73$ \\
\hline Labor hours & 15.8 & 6.3 & 196.5 & 170.0 \\
\hline Average labor cost & 787.50 & 312.50 & $9,825.00$ & $8,500.00$ \\
\hline Total cost (for system) & $1,193.32$ & 718.32 & $12,461.35$ & $11,060.73$ \\
\hline Total cost (for system) per bus & 29.83 & 17.96 & 445.05 & 395.03 \\
\hline Total cost (for system) per mile & 0.01 & 0.01 & 0.01 & 0.02 \\
\hline \multicolumn{5}{|c|}{ Brake System Repairs (ATA VMRS 13) } \\
\hline Parts cost & 619.56 & 619.56 & $18,128.69$ & $15,473.45$ \\
\hline Labor hours & 15.3 & 15.3 & 133.3 & 100.0 \\
\hline Average labor cost & 762.50 & 762.50 & $6,662.50$ & $5,000.00$ \\
\hline Total cost (for system) & $1,382.06$ & $1,382.06$ & $24,791.19$ & $20,473.45$ \\
\hline Total cost (for system) per bus & 34.55 & 34.55 & 885.40 & 731.19 \\
\hline Total cost (for system) per mile & 0.01 & 0.01 & 0.03 & 0.03 \\
\hline \multicolumn{5}{|c|}{ Transmission Repairs (ATA VMRS 27) } \\
\hline Parts cost & 0.00 & 0.00 & $2,189.64$ & $1,545.60$ \\
\hline Labor hours & 0.0 & 0.0 & 41.8 & 27.0 \\
\hline Average labor cost & 0.00 & 0.00 & $2,087.50$ & $1,350.00$ \\
\hline Total cost (for system) & 0.00 & 0.00 & $4,277.14$ & $2,895.60$ \\
\hline Total cost (for system) per bus & 0.00 & 0.00 & 152.76 & 103.41 \\
\hline Total cost (for system) per mile & 0.00 & 0.00 & 0.00 & 0.00 \\
\hline
\end{tabular}




\begin{tabular}{|c|c|c|c|c|}
\hline & $\begin{array}{l}\text { AFCB } \\
\text { All Data }\end{array}$ & $\begin{array}{l}\text { AFCB } \\
\text { New Data }\end{array}$ & $\begin{array}{l}\text { CNG } \\
\text { All Data }\end{array}$ & $\begin{array}{l}\text { CNG } \\
\text { New Data }\end{array}$ \\
\hline \multicolumn{2}{|c|}{$\begin{array}{l}\text { Inspections Only - no parts replacements } \\
\text { (101) }\end{array}$} & & & \\
\hline Parts cost & 0.00 & 0.00 & 0.00 & 0.00 \\
\hline Labor hours & 224.8 & 135.0 & 1221.3 & 828.8 \\
\hline Average labor cost & $11,237.50$ & $6,750.00$ & $61,062.50$ & $41,437.50$ \\
\hline Total cost (for system) & $11,237.50$ & $6,750.00$ & $61,062.50$ & $41,437.50$ \\
\hline Total cost (for system) per bus & 280.94 & 168.75 & $2,180.80$ & $1,479.91$ \\
\hline Total cost (for system) per mile & 0.07 & 0.06 & 0.07 & 0.06 \\
\hline \multicolumn{5}{|c|}{$\begin{array}{l}\text { Cab, Body, and Accessories Systems Repairs (ATA VMRS 02-Cab and Sheet Metal, 50- } \\
\text { Accessories, 71-Body) }\end{array}$} \\
\hline Parts cost & $3,125.55$ & $2,220.29$ & $29,265.38$ & $22,771.42$ \\
\hline Labor hours & 202.3 & 109.5 & $1,072.8$ & 715.8 \\
\hline Average labor cost & $10,112.50$ & $5,475.00$ & $53,637.50$ & $35,787.50$ \\
\hline Total cost (for system) & $13,238.05$ & $7,695.29$ & $82,902.88$ & $58,558.92$ \\
\hline Total cost (for system) per bus & 330.95 & 192.38 & $2,960.82$ & $2,091.39$ \\
\hline Total cost (for system) per mile & 0.09 & 0.07 & 0.09 & 0.09 \\
\hline \multicolumn{2}{|c|}{ HVAC System Repairs (ATA VMRS 01) } & & & \\
\hline Parts cost & 48.30 & 0.00 & $34,474.02$ & $29,336.27$ \\
\hline Labor hours & 14.0 & 9.0 & 370.5 & 318.0 \\
\hline Average labor cost & 700.00 & 450.00 & $18,525.00$ & $15,900.00$ \\
\hline Total cost (for system) & 748.30 & 450.00 & $52,999.02$ & $45,236.27$ \\
\hline Total cost (for system) per bus & 18.71 & 11.25 & $1,892.82$ & $1,615.58$ \\
\hline Total cost (for system) per mile & 0.00 & 0.00 & 0.06 & 0.07 \\
\hline \multicolumn{2}{|c|}{ Lighting System Repairs (ATA VMRS 34) } & & & \\
\hline Parts cost & 306.21 & 289.18 & $2,290.71$ & $1,391.35$ \\
\hline Labor hours & 22.8 & 16.5 & 140.5 & 106.8 \\
\hline Average labor cost & $1,137.50$ & 825.00 & $7,025.00$ & $5,337.50$ \\
\hline Total cost (for system) & $1,443.71$ & $1,114.18$ & $9,315.71$ & $6,728.85$ \\
\hline Total cost (for system) per bus & 36.09 & 27.85 & 332.70 & 240.32 \\
\hline Total cost (for system) per mile & 0.01 & 0.01 & 0.01 & 0.01 \\
\hline \multicolumn{5}{|c|}{ Frame, Steering, and Suspension Repairs (ATA VMRS 14-Frame, 15-Steering, 16-Suspension) } \\
\hline Parts cost & $1,595.40$ & $1,584.18$ & $4,898.58$ & $3,791.70$ \\
\hline Labor hours & 41.0 & 38.5 & 102.8 & 88.5 \\
\hline Average labor cost & $2,050.00$ & $1,925.00$ & $5,137.50$ & $4,425.00$ \\
\hline Total cost (for system) & $3,645.40$ & $3,509.18$ & $10,036.08$ & $8,216.70$ \\
\hline Total cost (for system) per bus & 91.14 & 87.73 & 358.43 & 293.45 \\
\hline Total cost (for system) per mile & 0.02 & 0.03 & 0.01 & 0.01 \\
\hline \multicolumn{5}{|c|}{$\begin{array}{l}\text { Axle, Wheel, and Drive Shaft Repairs (ATA VMRS 11-Front Axle, 18-Wheels, 22-Rear Axle, 24-Drive } \\
\text { Shaft) }\end{array}$} \\
\hline Parts cost & 0.00 & 0.00 & $6,545.12$ & $5,980.67$ \\
\hline Labor hours & 0.0 & 0.0 & 57.0 & 53.5 \\
\hline Average labor cost & 0.00 & 0.00 & $2,850.00$ & $2,675.00$ \\
\hline Total cost (for system) & 0.00 & 0.00 & $9,395.12$ & $8,655.67$ \\
\hline Total cost (for system) per bus & 0.00 & 0.00 & 335.54 & 309.13 \\
\hline Total cost (for system) per mile & 0.00 & 0.00 & 0.01 & 0.01 \\
\hline
\end{tabular}


Maintenance Costs by Vehicle System (continued)

\begin{tabular}{|c|c|c|c|c|}
\hline & $\begin{array}{c}\text { AFCB } \\
\text { All Data }\end{array}$ & $\begin{array}{c}\text { AFCB } \\
\text { New Data }\end{array}$ & $\begin{array}{c}\text { CNG } \\
\text { All Data }\end{array}$ & $\begin{array}{c}\text { CNG } \\
\text { New Data }\end{array}$ \\
\hline \multicolumn{5}{|l|}{ Tire Repairs (ATA VMRS 17) } \\
\hline Parts cost & 0.00 & 0.00 & 27.95 & 27.95 \\
\hline Labor hours & 17.5 & 11.8 & 156.5 & 101.5 \\
\hline Average labor cost & 875.00 & 587.50 & $7,825.00$ & $5,075.00$ \\
\hline Total cost (for system) & 875.00 & 587.50 & $7,852.95$ & $5,102.95$ \\
\hline Total cost (for system) per bus & 21.88 & 14.69 & 280.46 & 182.25 \\
\hline Total cost (for system) per mile & 0.01 & 0.01 & 0.01 & 0.01 \\
\hline
\end{tabular}

\section{Notes}

1. To compare the hydrogen fuel dispensed and fuel economy to diesel, the hydrogen dispensed was also converted into diesel energy equivalent gallons. Actual energy content will vary by locations, but the general energy conversions are as follows:

Lower heating value $(\mathrm{LHV})$ for hydrogen $=51,532 \mathrm{Btu} / \mathrm{lb}$

LHV for diesel $=128,400 \mathrm{Btu} / \mathrm{lb}$

$1 \mathrm{~kg}=2.205 * \mathrm{lb}$

$51,532 \mathrm{Btu} / \mathrm{lb}$ * $2.205 \mathrm{lb} / \mathrm{kg}=113,628 \mathrm{Btu} / \mathrm{kg}$

Diesel $/$ hydrogen $=128,400 \mathrm{Btu} / \mathrm{gal} / 113,628 \mathrm{Btu} / \mathrm{kg}=1.13 \mathrm{~kg} / \mathrm{diesel}$ gal

The gasoline LHV or GGE is $115,000 \mathrm{Btu} / \mathrm{gal}$, which is approximately $1 \%$ higher than 113,628

Btu/kg for hydrogen; these have been called equivalent for this report.

Gasoline/diesel $=115,000 \mathrm{Btu} / \mathrm{gallon} / 128,400 \mathrm{Btu} /$ gallon $=0.896$

2. The propulsion-related systems were chosen to include only those systems of the vehicles that could be affected directly by the selection of a fuel/advanced technology.

3. ATA VMRS coding is based on parts that were replaced. If there was no part replaced in a given repair, then the code was chosen by the system being worked on.

4. In general, inspections (with no part replacements) were included only in the overall totals (not by system). Category 101 was created to track labor costs for PM inspections.

5. ATA VMRS 02-Cab and Sheet Metal represents seats, doors, etc.; ATA VMRS 50-Accessories represents things like fire extinguishers, test kits, etc.; ATA VMRS 71-Body represents mostly windows and windshields.

6. Average labor cost is assumed to be $\$ 50$ per hour.

7. Warranty costs are not included. 


\section{Appendix C: Fleet Summary Statistics-SI Units}

\section{Fleet Summary Statistics: SunLine Transit Agency \\ AFCB and CNG Study Groups \\ Fleet Operations and Economics}

\begin{tabular}{|c|c|c|c|c|}
\hline & $\begin{array}{l}\text { AFCB } \\
\text { Total }\end{array}$ & $\begin{array}{l}\text { AFCB Data } \\
\text { Period }\end{array}$ & CNG Total & $\begin{array}{l}\text { CNG Data } \\
\text { Period }\end{array}$ \\
\hline Number of vehicles & 4 & 4 & 5 & 5 \\
\hline Period used for fuel and oil op analysis & $3 / 12-6 / 15$ & $3 / 13-6 / 15$ & $3 / 12-6 / 15$ & $3 / 13-6 / 15$ \\
\hline Total number of months in period & 40 & 28 & 40 & 28 \\
\hline Fuel and oil analysis base fleet kilometers & 236,680 & 167,499 & $1,441,510$ & $1,074,227$ \\
\hline Period used for maintenance op analysis & $3 / 12-6 / 15$ & $3 / 13-6 / 15$ & $3 / 12-6 / 15$ & $3 / 13-6 / 15$ \\
\hline Total number of months in period & 40 & 28 & 40 & 28 \\
\hline Maintenance analysis base fleet kilometers & 244,509 & 175,328 & $1,446,230$ & $1,078,939$ \\
\hline Average monthly kilometers per vehicle & 4,009 & 3,577 & 7,231 & 7,707 \\
\hline Availability & 70 & 66 & 85 & 88 \\
\hline Fleet fuel usage in $\mathrm{kg} \mathrm{H}_{2}$ or liter equiv. $\mathrm{CNG}$ & $24,085.2$ & $17,512.4$ & $1,183,705.5$ & $875,517.3$ \\
\hline Roadcalls & 39 & 28 & 105 & 77 \\
\hline Total KMBRC & 6,269 & 6,262 & 13,774 & 14,012 \\
\hline Propulsion roadcalls & 23 & 17 & 35 & 28 \\
\hline Propulsion KMBRC & 10,631 & 10,313 & 41,321 & 38,534 \\
\hline $\begin{array}{l}\text { Fleet kg hydrogen } / 100 \mathrm{~km}\left(1.13 \mathrm{~kg} \mathrm{H}_{2} / \text { gal diesel }\right. \\
\text { fuel) }\end{array}$ & 10.18 & 10.46 & & \\
\hline Rep. fleet fuel consumption (L/100 km) & 34.09 & 35.02 & 73.49 & 72.94 \\
\hline Hydrogen cost per kg & 8.00 & 8.00 & & \\
\hline CNG cost per liter & & & 0.26 & 0.26 \\
\hline Fuel cost per kilometer & 0.81 & 0.84 & 0.21 & 0.21 \\
\hline Total scheduled repair cost per kilometer & 0.05 & 0.04 & 0.06 & 0.06 \\
\hline Total unscheduled repair cost per kilometer & 0.26 & 0.30 & 0.27 & 0.28 \\
\hline Total maintenance cost per kilometer & 0.31 & 0.34 & 0.33 & 0.34 \\
\hline Total operating cost per kilometer & 1.13 & 1.17 & 0.55 & 0.55 \\
\hline
\end{tabular}

\section{Maintenance Costs}

\begin{tabular}{|l|r|r|r|r|}
\hline & AFCB Total & \multicolumn{1}{|c|}{$\begin{array}{c}\text { AFCB Data } \\
\text { Period }\end{array}$} & \multicolumn{1}{c|}{ CNG Total } & \multicolumn{1}{c|}{$\begin{array}{c}\text { CNG Data } \\
\text { Period }\end{array}$} \\
\hline Fleet mileage & 244,509 & 175,328 & $1,446,230$ & $1,078,939$ \\
\hline Total parts cost & $9,826.11$ & $8,317.38$ & $213,768.53$ & $172,980.67$ \\
Total labor hours & $1,323.3$ & $1,019.0$ & $5,394.8$ & $3,809.0$ \\
Average labor cost @ \$50.00 per hour) & $66,162.50$ & $50,950.00$ & $269,737.50$ & $190,450.00$ \\
Total maintenance cost & $75,988.61$ & $59,267.38$ & $483,506.03$ & $363,430.67$ \\
\hline Total maintenance cost per bus & $25,329.54$ & $19,755.79$ & $161,168.68$ & $72,686.13$ \\
\hline Total maintenance cost per kilometer & $\mathbf{0 . 3 1}$ & $\mathbf{0 . 3 4}$ & $\mathbf{0 . 3 3}$ & $\mathbf{0 . 3 4}$ \\
\hline
\end{tabular}

